\title{
The impact of the elderly on inflation rates in developed countries
}

\section{Article}

Published Version

Vlandas, T. (2016) The impact of the elderly on inflation rates in developed countries. LSE Europe in Question, March (107). pp. 1-66. Available at http://centaur.reading.ac.uk/61342/

It is advisable to refer to the publisher's version if you intend to cite from the work. See Guidance on citing.

Publisher: European Institute, London School of Economics

All outputs in CentAUR are protected by Intellectual Property Rights law, including copyright law. Copyright and IPR is retained by the creators or other copyright holders. Terms and conditions for use of this material are defined in the End User Agreement.

www.reading.ac.uk/centaur

\section{CentAUR}


Central Archive at the University of Reading

Reading's research outputs online 


\section{The impact of the elderly on inflation rates in developed countries}

Tim Vlandas

LEQS Paper No. 107/2016

March 2016 


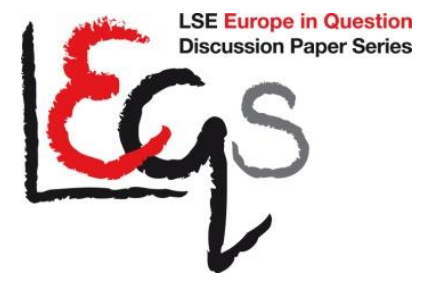

\section{Editorial Board}

Dr Abel Bojar

Dr Vassilis Monastiriotis

Dr Jonathan White

Dr Katjana Gattermann

Dr Sonja Avlijas

All views expressed in this paper are those of the author(s) and do not necessarily represent the views of the editors or the LSE.

(c) Tim Vlandas

\section{Eqs}




\title{
The impact of the elderly on inflation rates in developed countries
}

\author{
Tim Vlandas*
}

\begin{abstract}
What explains the cross-national variation in inflation rates in developed countries? Previous literature has emphasised the role of ideas and institutions, and to a lesser extent interest groups, while leaving the role of electoral politics comparatively unexplored. This paper seeks to redress this neglect by focusing on one case where electoral politics matters for inflation: the share of the population above 65 years old in a country. I argue that countries with a larger share of elderly have lower inflation because older people are both more inflation averse and politically powerful, forcing governments to pursue lower inflation. I test my argument in three steps. First, logistic regression analysis of survey data confirms older people are more inflation averse. Second, panel data regression analysis of party manifesto data reveals that European countries with more old people have more economically orthodox political parties. Third, time series cross-section regression analyses demonstrate that the share of the elderly is negatively correlated with inflation in both a sample of 21 advanced OECD economies and a larger sample of 175 countries. Ageing may therefore push governments to adopt a low inflation regime.
\end{abstract}

Keywords: ageing, inflation, elderly, economic policy, electoral politics, OECD

* Department of Politics and International Relations, University of Reading

Email: t.r.g.vlandas@reading.ac.uk 


\section{Table of Contents}

The political economy determinants of inflation rates ..................... 5

The conventional wisdom: ideas and institutions ..........................................5

Cross-national variation in inflation rates................................................

Bringing the third ' $i$ ' back in: Domestic interests and demographic

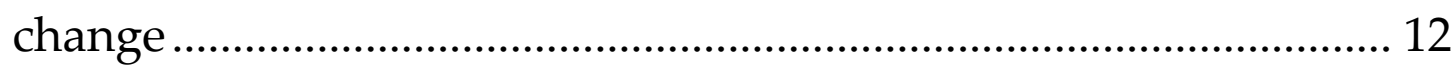

Domestic electoral politics ............................................................................12

The elderly, inflation preferences and political power....................................14

Grey power and political parties' manifestos......................................................19

Empirical tests of the determinants of inflation ............................... 22

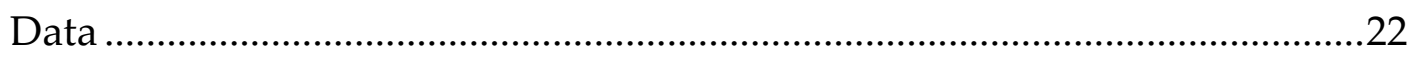

Estimation strategy and results....................................................................24

Dynamics of adjustments: Error Correction Model ...........................................36

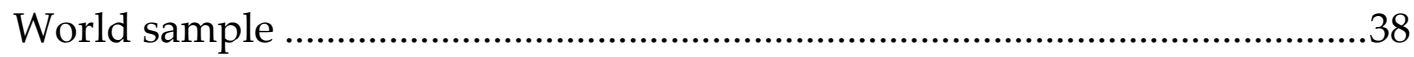

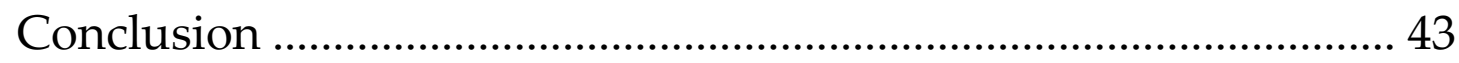

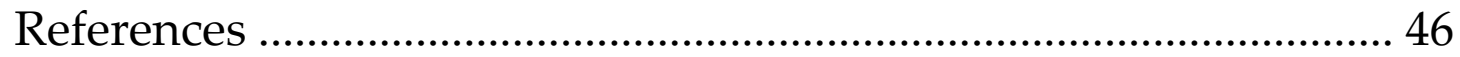

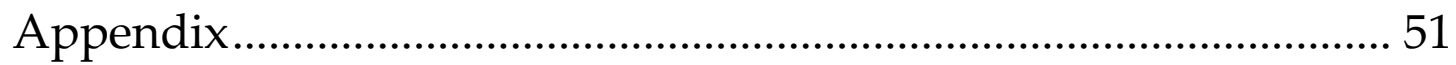




\section{The impact of the elderly on inflation rates in developed countries}

What explains the cross-national variation in inflation rate across developed countries? This question has been the focus of a large body of literature in both economics and comparative political economy. However, most studies to date have focused on the role of ideas, institutions and economic factors ${ }^{1}$, and to a lesser extent interest groups, ${ }^{2}$ while ignoring the role of electoral politics in particular. While the conventional wisdom captures part of the story for understanding variation in inflation rates, the relative absence of electoral politics is surprising in two respects. First, this absence is at odds with the prominent role attributed to domestic electoral politics in other policy domains, such as labour market policies, ${ }^{3}$ pensions, ${ }^{4}$ and the welfare state ${ }^{5}$ more generally. Second, inflation has clearly identifiable distributive effects among on parts of the population who should therefore care about the level of inflation.

In this paper, I contend that electoral politics matter in the sense that the preferences of the electorate have an impact on the variation of inflation rates across time and countries. By looking at the preferences of different groups, electoral politics makes it possible to understand why certain ideas and institutions are chosen in the first place. Addressing this gap also helps us make sense of the variation in inflation rates among countries that have fairly similar institutions and economies. However, showing that electoral politics

\footnotetext{
${ }^{1}$ E.g. Mc Namara 1998; Cuckierman 1992; Hancke 2013; Iversen 1999; Grilli, Masciandaro, and Tabellini 1991. The next section reviews this literature in more detail.

${ }^{2}$ For an exception focusing on financial sector's opposition to inflation see Posen 1993, 1995.

${ }^{3}$ E.g. Boix, 1999; Rueda, 2007.

4 E.g. Hauserman, 2010.

${ }^{5}$ E.g. Pierson 1994, 1998.
} 
The impact of the elderly on inflation rates in developed countries

matters requires sidestepping two methodological pitfalls. The first issue is that many factors that affect the electorate's preferences for inflation such as wages, employment status or assets are partly endogenous to inflation rates. ${ }^{6}$ The second issue is to find a characteristic of the electorate that can be reliably linked to inflation preferences both theoretically and empirically.

To address both pitfalls, I choose to focus on the share of the elderly - those above 65 years old - that is present in a country in a given year. The elderly are clearly inflation averse ${ }^{7}$ and the share of the elderly in a country is not determined by the inflation rate. In other words, the share of elderly is a good first case to investigate the impact of electoral preferences on inflation rates: it is highly correlated to factors that can be expected to influence inflation preferences but is not itself determined by inflation rates. The presence of the elderly in OECD countries ${ }^{8}$ has also varied greatly over time and across countries. In 1960, less than $10 \%$ of the population in most OECD countries were above $65 \%$. By 2010, all OECD countries had more than 10\% elderly and most of the OECD this was higher than $15 \%$, while in Germany and Japan the elderly amounted to $20 \%$ of their population.

I argue that the demographic profile of countries has important consequences for economic outcomes as governments must increasingly take into account the economic policy preferences of the elderly. I make this claim in the case of inflation rates across developed economies and show that countries with more elderly exhibit lower inflation because old people are both more inflation averse and politically powerful. My argument enfolds in three steps.

\footnotetext{
${ }^{6}$ For instance, if one looked at the unemployed as a case of a group that is not particularly inflation averse, and unemployment has some relationship to inflation, then our independent variable would be endogenous to our dependent variable.

${ }^{7}$ Scheeve 2004.

${ }^{8}$ I refer to the following 21 OECD countries: Australia, Austria, Belgium, Denmark, Finland, France, Germany, Greece, Italy, Spain, Portugal, Greece, Japan, New Zealand, Netherlands, Norway, United Kingdom, United States.
} 
First, I argue that pensioners are more indifferent to unemployment than the rest of the population but are concerned about the value of their savings and pensions. As a result they are likely to oppose inflation much more than members of the labour force whose livelihood depends first and foremost on their employment prospects and are therefore more concerned about unemployment than inflation. I also document the political strength of the elderly in all developed countries. While important, this first step builds mostly on existing literature and is therefore not particularly controversial.

In the second and third steps, I discuss the macroeconomic implications of having inflation averse and politically powerful elderly population. I verify empirically the full causal chain of my argument. I start by arguing that political parties are influenced by the share of elderly in their electorate. Using panel data regression analysis of party manifesto data, I find that political parties in countries with a larger share of elderly have more economically orthodox manifestos. The third step is a logical implication of the first two: countries with more elderly should ceteris paribus exhibit lower inflation rates. The underlying mechanism is straightforward: a larger share of elderly in an economy makes them a more powerful constituency whose preferences for low inflation are more likely to be taken into account by both conservative and social democratic parties, which in turn push for low inflation when in power. I test this final step using a battery of panel data regression analyses on a sample of 21 OECD countries since the 1960s. These results hold using a wide variety of specifications and estimation methods. Using an Error Correction Model, I also analyse the long run dynamics of adjustment in inflation rates in response to a larger share of elderly. Using a structural equation model, I show that the share of the elderly has both a direct effect on inflation and an indirect effect by being correlated to higher central bank independence. As a robustness check, I extend my analysis to the 
The impact of the elderly on inflation rates in developed countries

world by running a regression analysis on a much larger sample for 175 countries for which data is available.

While focused on the impact of a key independent variable on inflation, my findings advance our understanding of both inflation and ageing. First, they suggest that as countries age, achieving low inflation becomes an increasingly strong political imperative, regardless of what may be economically desirable. Second, if ageing has an important effect on such a crucial economic outcome, this opens up the question of the impact of ageing on other economic policies and outcomes. Third, this paper has focused on the role of demographic politics but further research should extend the analysis to other important facets of electoral politics that affect inflation.

The rest of the paper enfolds as follows. The next section reviews previous literature and maps the recent cross-national variation in inflation rates. Next, I present my argument concerning the impact of the elderly on inflation. I argue the elderly are both politically powerful and inflation averse, and show that political parties in countries with more elderly are more economically orthodox. The third section then tests the expectations of my model concerning the relationship between the share of elderly and inflation rates. The last section concludes with some implications for further research. 


\title{
The political economy determinants of inflation rates
}

\author{
The conventional wisdom: ideas and institutions
}

Two main approaches in comparative political economy have sought to explain inflation rates in developed economies - both ignoring electoral politics. The first approach has focused on the role of ideas. In this approach, a new dominant economic narrative, new classical economics ${ }^{9}$ - and within it monetarism ${ }^{10}$ - convinced policy makers that any monetary induced short term employment gains fade away over the long run while resulting in higher inflation. This in turn made low inflation policies more appealing to government officials ${ }^{11}$ and resulted in a shift away from the Keynesian consensus that had prevailed in the post war era until then. ${ }^{12}$

However, this shift in the prevailing ideas concerning the optimal inflation rate also created a dilemma, namely how to achieve this lower inflation target in a context where policy makers may be tempted, for electoral gains, to pursue short term goals ${ }^{13}$ that may raise inflation? This created a particularly acute problem for the left which was seeking ways to lower the interest rate premia they were charged when in power. ${ }^{14}$ Various solutions were proposed, for instance tying future governments' hands, ${ }^{15}$ or trying to convince the electorate that governments have no alternatives but to an pursue unpopular monetary policy. ${ }^{16}$ One solution to the time inconsistency

\footnotetext{
${ }^{9}$ Soskice and Iversen 2006.

${ }^{10}$ Alt and Chrystal 1983; Friedman 1968.

11 E.g. Mc. Namara 1998.

12 Hall 1986.

${ }_{13}$ Alesina et al. 1997; Nordhaus 1975; McRae 1977.

${ }^{14}$ Garrett 1998; Goodhart 1997; Capie et al. 1994.

15 Goodman 1991; Clark 1998.

${ }^{16}$ Etzel 1990; Woolley 1984; Bernhard 1996.
} 
The impact of the elderly on inflation rates in developed countries

problem that gained prominence was to fully delegate monetary policy to independent central banks thereby convincing all actors that the commitment to low inflation was credible. ${ }^{17}$ Joining the European Monetary Union (EMU) and delegating monetary policy to the European Central Bank raised the political costs of inflation because governments' low inflation commitments would be closely monitored by private sector agents. ${ }^{18}$ As a result, agents would expect low inflation and this in turn becomes a self-fulfilling prophecy even in the absence of a monetary policy tightening. ${ }^{19}$ The problem with the ideational approach is what it leaves unanswered, namely whose ideas dominate policy making and why ${ }^{20}$ In addition, most of this literature has been concerned with explaining the shift to a low inflation regime over time, making it difficult to use ideas to explain the cross-national variation in inflation rates we observe.

A second stream of literature emphasises the role of domestic institutions. It emphasises in particular the role of independent central banks ${ }^{21}$ which are themselves seen as institutionalising the ideational consensus discussed above. Because central banks were seen as more conservatives - in the sense that they prefer lower inflation than elected governments - and less receptive to electoral pressures, independence should lead to lower inflation ${ }^{22}$ as well as lower partisan and electoral political cycles in inflation rates. ${ }^{23}$

However, the effect of independent central banks on inflation may depend on

\footnotetext{
17 Barro and Gordon, 1983; Barro and Gordon, 1983b; Rogoff and Sibert 1988; Alesina; 1989.

18 Giavazzi and Pagano 1988.

19 Grilli et al. 1991.

${ }^{20}$ Mc. Namara (1998) does discuss what made the new paradigm attractive: a combination of policy failure (in dealing with oil shock), policy innovation (monetarism) and policy emulation (seeing Germany as an example of good policy). Here I do not wish to suggest that these are irrelevant, rather that this must be completed by an analysis of electoral constraints.

${ }^{21}$ Cuckierman 1992; Eijffinger and de Haan 1996; Debelle and Fischer 1994; Cuckierman, Webb and Neyapti 1991; Bade and Parkin 1984.

22 Roggoff 1985.

${ }^{23}$ Franzese 2003; Clark 2003; Way 2000.
} 
other institutions. There is for instance some evidence that the effect of central bank independence may also be contingent on whether governments are weak. ${ }^{24}$ But more important than the structure of governments is the institutional environment in which employees and employers bargain wages. A significant literature has stressed the importance of wage bargaining institutions and unions. ${ }^{25}$ For instance, in the Keynesian era, unions moderated their wages in exchange for long term gains ${ }^{26}$. In countries with neocorporatist institutions, ${ }^{27}$ unions had greater incentives to exercise wage restraint because governments were offering them various benefits in return, thereby minimising both inflation and unemployment if wage moderation was coupled with the right fiscal and monetary policies. ${ }^{28}$

These two approaches are not mutually exclusive. It is in principle possible that both institutions and ideas jointly determine inflation rates. For instance, the effect of having an independent central bank on inflation rates fell as policy makers increasingly adopted low inflation preferences ${ }^{29}$. These two approaches are valuable in analysing how various institutions and ideas affect inflation rates given certain interests in society, but this says very little about what these interests are and how they may in turn explain inflation. To the extent that this literature focuses on the origins of these institutions, this is either to be found in ideas or in the interests of different sectors of the economy, where the export sector has a strong interest in retaining competitiveness and keeping inflation low. However, when choosing institutions governments cannot be assumed to entirely disregard electoral constraints, and even when institutions are already given, governments could

\footnotetext{
24 Sakamoto 2005.

25 Franzese 1999, 2003; Hall and Franzese 1998; Iversen 1999.

26 Eichengreen 1997; Iversen and Soskice 2006.

27 Cameron 1984; Lange and Garrett 1985; Calmfors and Driffill 1988.

28 Cf. Scharpf 1987.

29 Kaltenthaler and Anderson 2000.
} 
The impact of the elderly on inflation rates in developed countries

still in principle influence inflation rates through other policies (e.g. fiscal policy, welfare state benefits).

\section{Cross-national variation in inflation rates}

Ideas cannot easily explain cross-national variation by design, 30 but the relationship between central bank and wage bargaining institutions on the one hand and inflation on the other hand requires more scrutiny. Figure 1 shows the cross-national variation in the consumer price index and central bank independence in 1998 (i.e. before the European Central Bank took over monetary policy responsibility from national central banks in Eurozone countries) ${ }^{31}$. It shows that while many soon-to-become members of the European Monetary Union had fairly similar degrees of central bank independence, several percentage point variation in inflation rates remained between low and high inflation performers. Countries with very dissimilar central banks exhibited only small differences in inflation rates: pair of countries such as Spain and Denmark, Ireland and Norway, or France and Japan, had similar inflation rates despite having different degrees of central bank independence. The correlation coefficient between inflation and central bank independence in a sample of 21 OECD countries since 1960 is negative and significant (at the $1 \%$ level) but not particularly large $(-0.16)$.

Previous literature discussed earlier would make us expect that wage coordination and the size of the export sector may also matter: governments in countries with sizeable and well-coordinated export sector have both the ability and willingness to keep inflation low to retain their competitive

\footnotetext{
${ }^{30}$ Here I refer to ideas that spread across parties in all countries, but of course it is possible to test the impact of partisanship on inflation, which I do in the empirical section.

${ }^{31}$ All the data displayed in this sub-section are discussed in detail in the empirical section of the paper and in the appendix.
} 
advantage in trade. Figures 2 and 3 display the relationship between inflation and wage coordination as well as trade openness as \% of GDP, respectively, in 1998. Countries ranked as having similar wage coordination have vastly different inflation performance (e.g. Japan, Austria, Sweden, Norway and Ireland) while countries with similar inflation performance (e.g. Finland and the UK, or Japan and France) had different wage coordination indices. The correlation coefficient between inflation and wage coordination in a sample of 21 OECD countries since 1960 is - 0.0187 (non-significant p-value of 0.5435 ). The picture for trade openness is similarly mixed (Figure 3, year 1998): France and Australia had lower inflation rates than Ireland and the Netherlands despite having much lower levels of trade openness. Belgium and Australia had almost identical inflation rates despite having more than 40 percentage points differences in their export to GDP ratios. The correlation coefficient between inflation and trade openness in a sample of 21 OECD countries since 1960 is -0.1450 (significant p-value of 0.000 ).

One could of course object that bivariate correlations can never be perfect since there may be ommitted variables, interaction effects, etc. Therefore, here I do not wish to suggest that existing explanations can be disproved. Rather I make the more modest claim that some of this unexplained variation can be explained by a focus on domestic electoral politics. In other words, my explanation should be seen as potentially complementary rather than substituting for existing explanations.

As I discuss in the next section, I posit that the share of the elderly is negatively correlated with inflation because the old are inflation averse, politically powerful, and ultimately influence government policies and in turn inflation rates. A similar examination of the bivariate relationship between inflation rates and the share of elderly in the population reveals a much 
The impact of the elderly on inflation rates in developed countries

stronger correlation (Figure 4). The correlation coefficient between inflation and the share of elderly in a sample of 21 OECD countries since 1960 is 0.2797 (significant p-value of 0.000 ). Thus, on bivariate correlations alone, the share of the elderly looks like a reasonable addition to existing explanations. In the next section I locate my argument in the literature on the domestic politics of inflation and argue that the old are both more inflation averse and have sufficient political power to push through their preferences for low inflation onto party manifestos.

Figure 1: Consumer price index and central bank independence in 1998

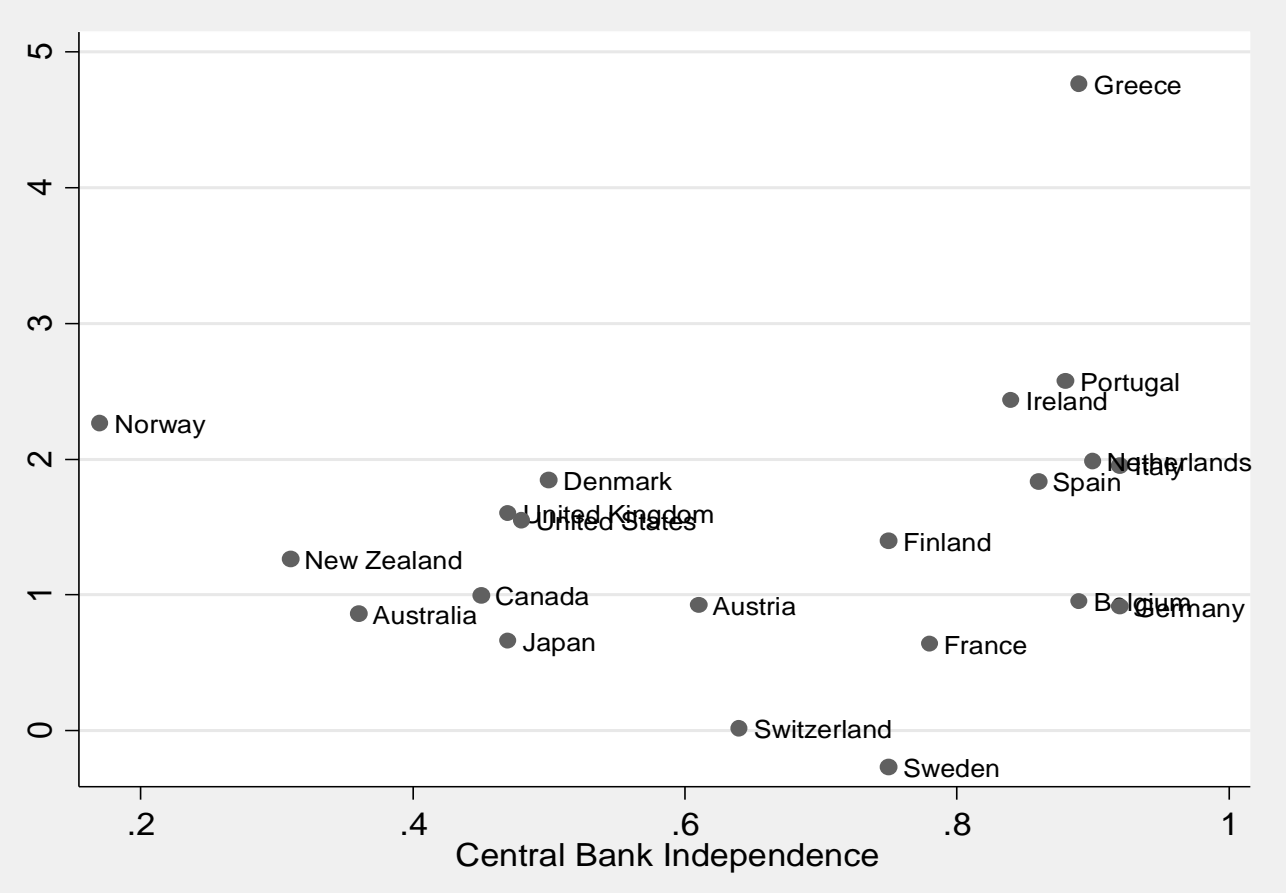


Figure 2: Consumer price index and wage coordination in 1998

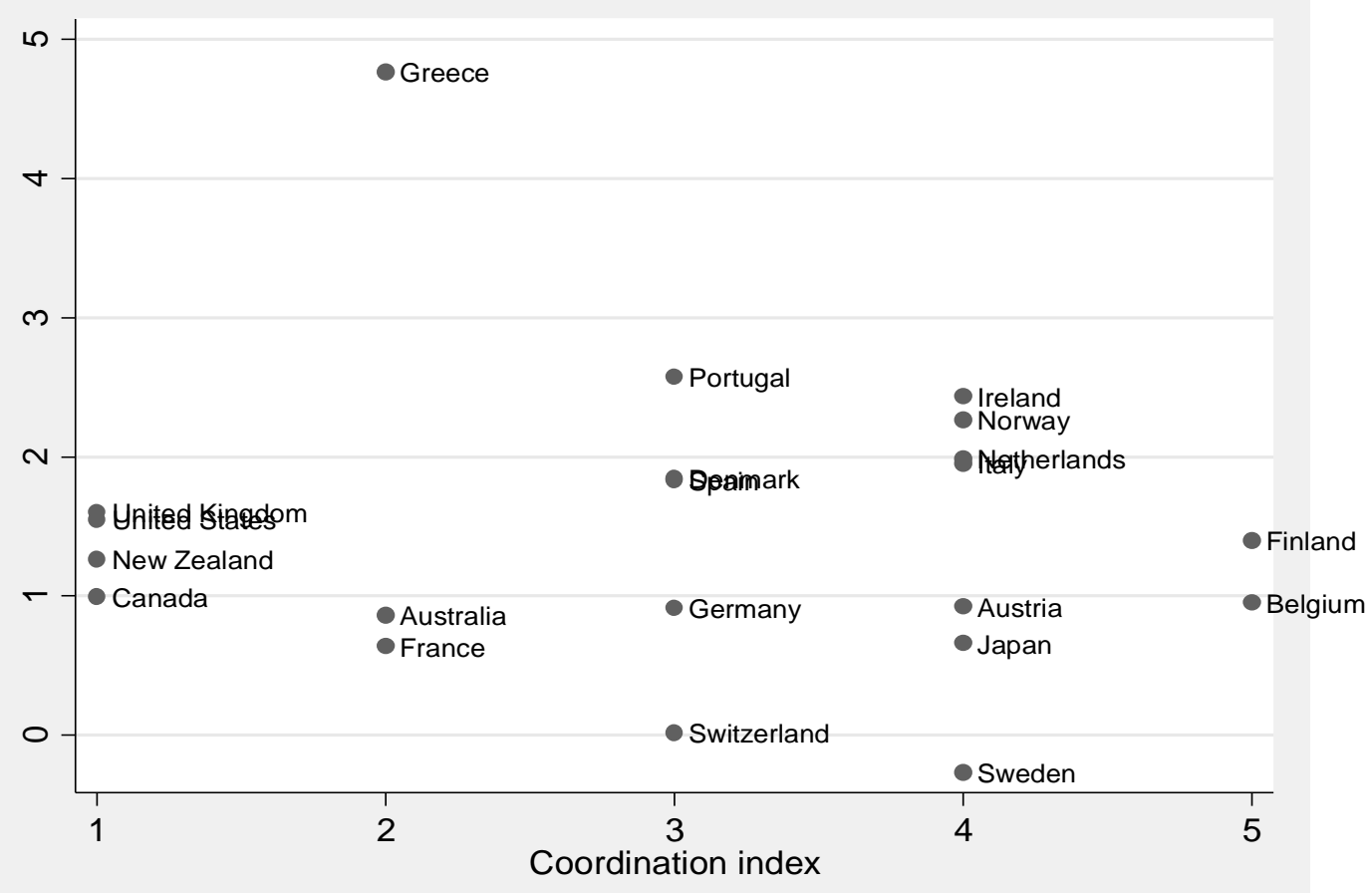

Figure 3: Consumer price index and exports as a share of GDP

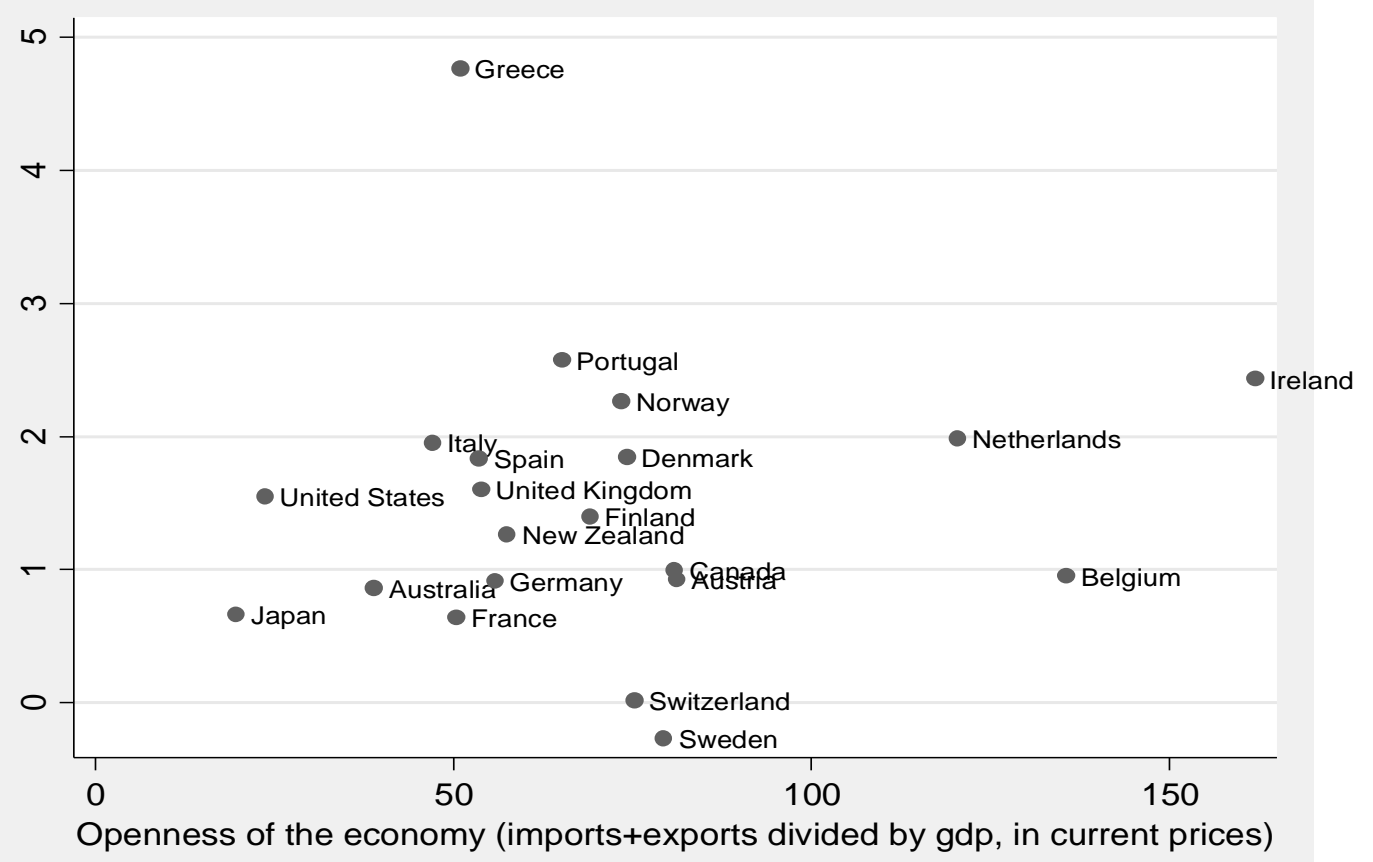


The impact of the elderly on inflation rates in developed countries

Figure 4: Consumer price indexand population over 65 as a share of total population

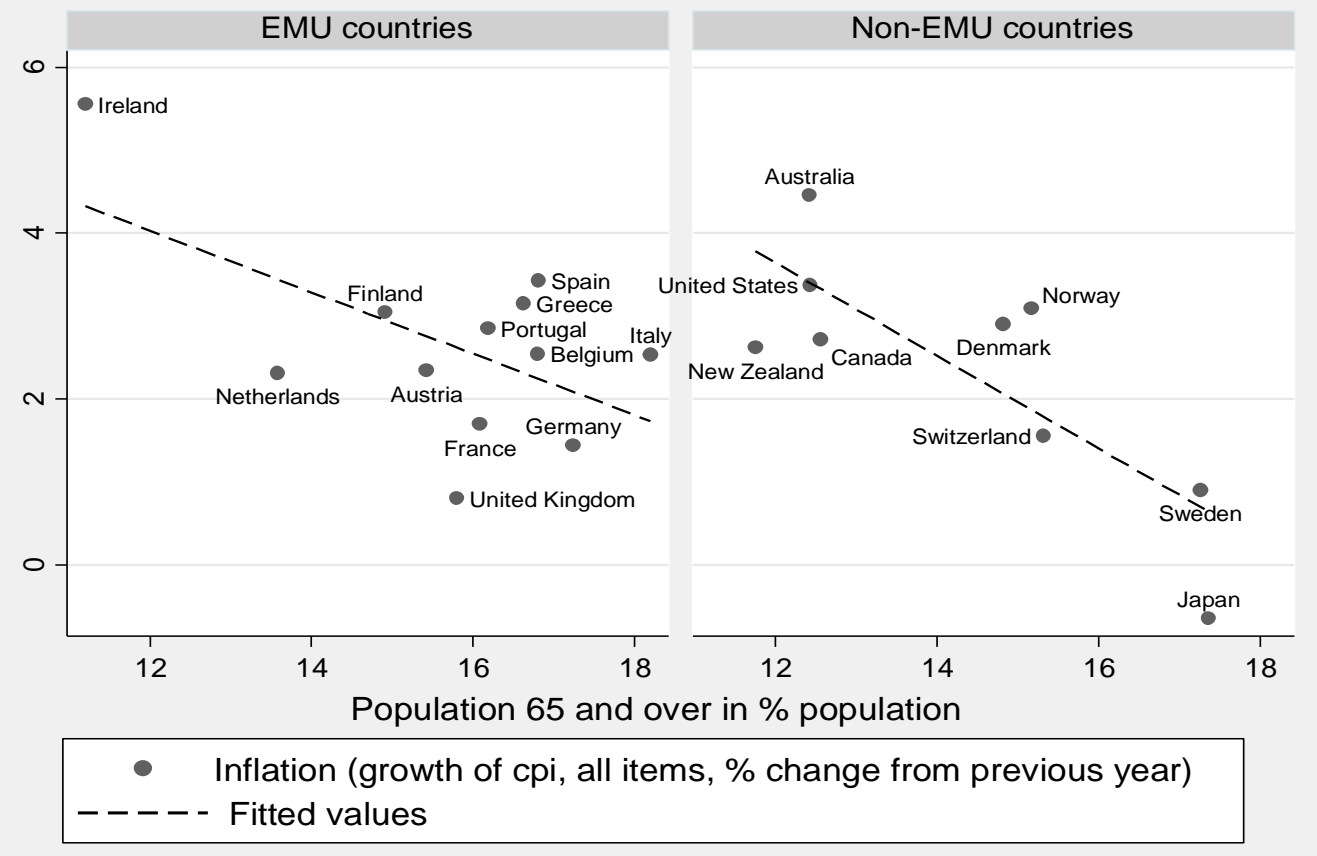

Bringing the third ' $i$ ' back in: Domestic interests and demographic change

Domestic electoral politics

In stressing the role of domestic politics, this paper builds on Posen's ${ }^{32}$ contention that central bank independence may itself be explained by other factors which would therefore have causal primacy in explaining inflation rates. Specifically, he showed that, because of its preference for low inflation, the financial sector has a pivotal role in supporting price stability in the long run $^{33}$. Rather than being a cause of low inflation, central bank independence

32 Posen 1993 and 1995b.

33 Posen, 1995a. 
was itself determined by the financial sector's opposition to inflation. If this is true, both low inflation and central bank independence are more likely in countries with stronger financial actors, ${ }^{34}$ whether because of lobbying on the parts of financial actors ${ }^{35}$ or through the discipline of capital markets. ${ }^{36}$ Cuckierman had in $1992^{37}$ similarly suggested that the likelihood of making central bank independents was a function of the size of financial markets and subsequent literature has by and large confirmed Posen's ${ }^{38}$ contention that central bank independence and low inflation requires political support to be sustained in the long run. ${ }^{39}$

While valuable this latter treatment focuses on interest groups rather than electoral dynamics, which had been the focus of older studies in comparative political economy. Several decades ago, Hibbs argued that the left and right have different inflation-employment preferences because their respective constituencies are differently affected by inflation and unemployment. ${ }^{40}$ These earlier studies by Hibbs therefore suggested that domestic politics cannot be ignored. However, even these treatments fail to consider changes in the electoral composition that affect both left and right, in which case the effect would not necessarily operate via left-right differences in government policies. For instance, there is some evidence that past trauma with hyperinflation played an important role in Germany's decision to delegate monetary policy to the Bundesbank. ${ }^{41}$ Over the long run, changes in the electorate's preferences may be more important than differences between distinct parts of the electorate at one point in time.

\footnotetext{
34 Posen 1993.

35 Posen 1995b.

${ }^{36}$ Maxfield 1997. Note that I test the effect of both capital market openness and the size of the stock market in the empirical section of the paper.

${ }^{37}$ Cuckierman 1992.

38 Posen 1993, 1995.

${ }^{39}$ Berger, Eijffinger and De Haan 2001; Hayo 1998; Kuttner and Posen 2009; and Miller 1998.

40 E.g. Hibbs 1977 and 1986.

${ }^{41}$ Issing 1993, pp 18.
} 
The impact of the elderly on inflation rates in developed countries

Rather than focusing on partisan differences or events in the past that affect the whole electorate, I focus here on how different groups in the population may have distinct inflation preferences and how the size of these groups may in turn feed into differences in inflation rates across countries. That inflation has distributional consequences is not controversial 42 and this occurs regardless of the degree of central bank independence. ${ }^{43}$ As discussed in the introduction, one difficulty in estimating the effect of the electorate's preferences on inflation is that inflation itself may affect the characteristics of the electorate that shape their preferences. It is therefore crucial to use a criterion for identifying inflation averse groups that is as much as possible exogenous to inflation. One such criterion is age. The old that have retired should care less (or not at all) about their employment prospect, since they derive their income from pensions and/or assets - rather than employment, and are often net creditors, having repaid debts accumulated through mortgages. ${ }^{44}$ By contrast, the young and/or those in the labour force tend to care more about employment than inflation given that most of their income depends on working and that they are often net debtors. 45

\section{The elderly, inflation preferences and political power}

What is the evidence concerning older people's inflation preferences? In a recent study, Scheeve analysed public inflation aversion and found that older individuals are more inflation averse because they "are more likely to have significant nominal assets and/or to rely on fixed incomes". ${ }^{46}$ Using both

\footnotetext{
42 Briault 1995; Fischer 1994; Laidler 1997.

43 Posen 1995b; Walsh 1994.

${ }^{44}$ Note that throughout the discussion about elderly's preferences is relative: what matters is their inflation preferences relative to the rest of the population, and similarly for their position in terms of income sources, asset wealth, etc.

$45 \mathrm{cf}$. Bach and Stephenson 1974.

46 Scheeve 2004, pp 11.
} 
Eurobarometer and International Social Survey Program data, results from a logit regression show that older respondents are indeed more inflation averse and this holds when controlling for labour market status, ideology, education, income quartile and including country effects. ${ }^{47}$ Note that consistent with previous explanations focusing on the financial sector, those employed in that sector are more inflation averse and country level trade openness increases the likelihood of respondents being inflation averse ${ }^{48}$. He concluded that "this article provides substantial evidence that there is sufficient variation in public macroeconomic priorities across countries for the specification of preferences to be significantly improved by accounting for the relative inflation aversion of citizens". ${ }^{49}$

These results are compelling, but it is worth testing my assumption concerning the elderly's inflation preferences again briefly here for illustrative purposes. To do so, I rely on the Mannheim Eurobarometer Trend File covering the period 1970 to $2002^{50}$ and including the following countries: Belgium, Denmark, Germany, Finland, France, Greece, Ireland, Italy, Luxembourg, the Netherlands, Austria, Portugal, Sweden, Spain, and the United Kingdom. My dependent variable is coded 1 if respondents identify inflation as their first or second priority. My analysis controls for the gender and educational level of the respondent and I include robust standard errors clustered by country as well as country and year dummies to capture unobserved heterogeneity. To test my assumption, I rely on a variable capturing the age of the respondent and as an alternative a binary variable capturing whether the respondent is retired.

\footnotetext{
47 Scheeve 2004, pp 17, 18.

48 Scheeve 2004, pp 19.

49 Scheeve 2004, pp 29.

${ }^{50}$ Data Set Edition v2.0.1, Schmitt and Scholz 2005.
} 
The impact of the elderly on inflation rates in developed countries

The results from a logit analysis are shown in table 1. In line with Scheeve's results, column 1 suggests that retired respondents are more likely to choose inflation as their first or second priority. Female respondent are more likely to be inflation averse while education makes respondents less inflation averse. Column 2 shows that the older the respondent the more inflation averse their preferences. In column 3, I control for the country specific income group in which the respondent is located (not shown here but suggests higher income respondents are less inflation averse): the results for age are less strong but still significant. In column 4, I also control for left-right self-placement (more right wing respondents are more inflation averse) and union membership (union members are less inflation averse) and being retired still makes you more inflation averse. My findings here are not meant to be an exhaustive test of inflation preferences since they essentially re-affirm what is already shown in Scheeve's more systematic study of this topic.

Why does this difference in inflation preference matter? Developed economies have experienced a significant ageing of their population. ${ }^{51} \mathrm{How}$ to define the old is not a straightforward matter: Goerres discusses the pros and cons of different approaches and sets the cut-off point at 60 years old, arguing that this is the median age of retirement. ${ }^{52}$ This is a sensible cut off point for his purposes, since the EU average exit age from the labour force was 61.5 years old in 2010,53 but for the purpose of minimizing the risk of capturing people who are not yet retired in our measure of inflation averse old people, it is safer to put the cut-off point at $65 .{ }^{54}$ Using this cut-off point, almost $20 \%$ of the population in the Euro area was above 65 , and $5 \%$ above 80 .

\footnotetext{
51 Tepe and Vanhuysse 2009; Lynch and Myrskylä 2009, Sinn and Uebelmesser 2002.

52 Goerres 2009, pp 1-10.

${ }^{53}$ European Commission 2014, pp 51.

${ }^{54}$ Of course, one could directly use the share of the retired but this choice entails two problems. First, there is no readily available data since the 1960s for 21 OECD countries - to my knowledge. Second, the share of the population that is retired is much of government policies.
} 
The old age dependency ratio (share of 65+ over those between 15 and 64) increased from $12.5 \%$ in 1950 to $23.8 \%$ in 2010,55 while the numbers for Africa range from 5.9 to $6.1 \%$, for Asia from $6.8 \%$ to $9.9 \%$, and for Latin America from $6.2 \%$ to $10.6 \%$. By 2050 , the share over 65 will reach almost $30 \%$ in the European Union, with more than $10 \%$ above 80 years old. ${ }^{56}$

The old are not only increasing in number, they are also a group with considerable political power. ${ }^{57}$ Indeed, older people in Europe are more likely to vote ${ }^{58}$ and are much more likely to be members of political parties. ${ }^{59}$ The 60-69 age group is more likely to be union members than every over age group except 50 to 59 years old. ${ }^{60}$ If older people are more inflation averse and are politically powerful, it follows that their electoral power increases ceteris paribus with their numbers. As a result, political parties can be expected to be more anti-inflationary in countries with a larger share of elderly, and the governing party consequently pursues less inflationary policies in such countries. If this is correct, countries with a larger share of elderly population should exhibit lower inflation rates. This prediction can be tested because there is important cross-national variation in the share of over 65: for instance in 2013, the share over 65 in Europe varied from 21\% in Germany to 12\% in Ireland. ${ }^{61}$ In the world the variation is even stronger: from 3\% in Kuwait to $25.5 \%$ in Japan. ${ }^{62}$

To clarify, my argument is not that the share of elderly is the only factor that matters, nor that it is necessarily the most important factor (though this is

\footnotetext{
55 European Commission 2014, pp 23.

56 European Commission 2014, pp 410.

57 E.g. Goeres 2009; Sinn and Uebelmesser 2002.

58 Goerres 2007.

${ }^{59}$ Goerres 2009, see chapter 5.

60 Goerres, 2009, see table 5.1.

${ }^{61}$ European Commission 2014, pp 21.

62 United Nations database 2004, cited in Goerres 2009.
} 
The impact of the elderly on inflation rates in developed countries

certainly possible and ultimately an empirical matter). Rather, this paper makes the more modest claim that the share of the elderly is a strong determinant of inflation rates alongside other institutional (e.g. central bank independence) and economic (e.g. trade openness) factors.

Table 1: The determinants of inflation aversion

\begin{tabular}{|c|c|c|c|c|}
\hline \multirow{3}{*}{$\begin{array}{l}\text { Column } \\
\text { Retired } \\
\text { respondent }\end{array}$} & (1) & (2) & (3) & (4) \\
\hline & $0.16^{* * *}$ & & & $0.19^{* * *}$ \\
\hline & $(0.041)$ & & & $(0.054)$ \\
\hline Age & & $\begin{array}{l}0.01^{* * *} \\
(0.001)\end{array}$ & $\begin{array}{l}0.004^{* *} \\
(0.001)\end{array}$ & \\
\hline Female & $0.22^{* * *}$ & $0.21^{* * *}$ & $0.20^{* * *}$ & $0.17^{* * *}$ \\
\hline & $(0.031)$ & $(0.030)$ & $(0.031)$ & $(0.030)$ \\
\hline Education & $\begin{array}{l}-0.12^{* * *} \\
(0.006)\end{array}$ & $\begin{array}{l}-0.12^{* * *} \\
(0.007)\end{array}$ & $\begin{array}{l}-0.10^{* * *} \\
(0.005)\end{array}$ & $\begin{array}{l}-0.12^{* * *} \\
(0.006)\end{array}$ \\
\hline Union member & & & & $\begin{array}{l}-0.04^{* *} \\
(0.014)\end{array}$ \\
\hline $\begin{array}{l}\text { Left-Right } \\
\text { (higher values } \\
\text { more right) }\end{array}$ & & & & $\begin{array}{c}0.02^{* *} \\
(0.005)\end{array}$ \\
\hline Constant & $\begin{array}{l}1.24^{* * *} \\
(0.084)\end{array}$ & $\begin{array}{l}1.52^{* * *} \\
(0.123)\end{array}$ & $\begin{array}{l}1.55^{* * *} \\
(0.134)\end{array}$ & $\begin{array}{l}0.46^{* * *} \\
(0.075)\end{array}$ \\
\hline $\begin{array}{l}\text { Country fixed } \\
\text { effects }\end{array}$ & Yes & Yes & Yes & Yes \\
\hline Time effects & Yes & Yes & Yes & Yes \\
\hline Observations & 450,412 & 461,431 & 353,925 & 156,684 \\
\hline $\begin{array}{l}\text { Pseudo R- } \\
\text { squared }\end{array}$ & 0.08 & 0.08 & 0.09 & 0.08 \\
\hline
\end{tabular}




\section{Grey power and political parties' manifestos}

To test whether this is indeed the case, I proceed in three steps. First, in the remainder of this section, I show that parties are more inflation averse in countries with more elderly. Unfortunately there is to my knowledge no direct measure of anti-inflation preferences of all political parties in OECD countries. But the party manifesto dataset project ${ }^{63}$ which codes all party manifestos along several dimensions since the 1950s, has a variable that comes close called 'Economic Orthodoxy' (per414). This variable captures whether the party manifesto refers to "support for a strong currency". It also captures factors that likely have an effect on inflation such as "reduction of budget deficits", and "thrift and savings in the face of economic hardship". Higher values mean that there are more references to economic orthodoxy in a given manifesto in a country's election.

My dependent variable captures the average across all political parties' manifestos since my argument is about how a large group of voters that are opposed to inflation forces political parties to shift their policy preferences towards inflation. Because elections take place at different points in time depending on the country under consideration and since an immediate effect is implausible, I compute decade averages since the 1960s for 21 OECD countries. The results controlling for country fixed effects and time effects, as well as a number of factors ${ }^{64}$ that may plausibly affect manifestos are presented in table 2. Note that this is not meant to be an exhaustive analysis of the determinants of party manifestos but merely to substantiate a link between the share of elderly and economic orthodoxy. The results are broadly consistent with this claim: countries with more elderly as a percentage of their

\footnotetext{
63 Volkens et al. 2014.

64 See next section for definitions and sources.
} 
The impact of the elderly on inflation rates in developed countries

total population exhibit more economically orthodox political parties, when controlling for existing levels of inflation, deficits, unemployment, trade openness, trade union density and left presence in the cabinet.

Table 2: The share of elderly and economic orthodoxy in party manifesto

\begin{tabular}{|c|c|c|c|c|c|}
\hline Columns & (1) & $(2)$ & (3) & (4) & (5) \\
\hline \multirow[t]{2}{*}{ Share of elderly } & $0.18^{*}$ & $0.19 *$ & $0.19 *$ & $0.18^{*}$ & $0.17^{*}$ \\
\hline & $(0.068)$ & $(0.076)$ & $(0.076)$ & $(0.076)$ & $(0.066)$ \\
\hline \multirow[t]{2}{*}{ Inflation } & & -0.05 & -0.07 & -0.09 & -0.10 \\
\hline & & $(0.085)$ & $(0.088)$ & (0.094) & $(0.087)$ \\
\hline Trade openness & & 0.02 & 0.01 & 0.01 & 0.01 \\
\hline (\% of GDP) & & $(0.011)$ & $(0.013)$ & $(0.013)$ & $(0.011)$ \\
\hline \multirow[t]{2}{*}{ Unemployment rate } & & & -0.001 & -0.01 & -0.03 \\
\hline & & & $(0.061)$ & $(0.062)$ & $(0.067)$ \\
\hline \multirow[t]{2}{*}{ Deficit } & & & 0.04 & 0.03 & 0.03 \\
\hline & & & $(0.077)$ & $(0.076)$ & $(0.077)$ \\
\hline \multirow[t]{2}{*}{ Union density } & & & & 0.01 & 0.01 \\
\hline & & & & $(0.014)$ & $(0.014)$ \\
\hline Left control & & & & & 0.01 \\
\hline (\% cabinet) & & & & & $(0.006)$ \\
\hline \multirow[t]{2}{*}{1970 s period dummy } & -0.19 & -0.09 & 0.50 & 0.55 & 0.52 \\
\hline & $(0.543)$ & $(0.762)$ & $(0.859)$ & $(0.867)$ & $(0.821)$ \\
\hline \multirow[t]{2}{*}{ 1980s period dummy } & 0.21 & 0.08 & 0.58 & 0.66 & 0.67 \\
\hline & $(0.460)$ & $(0.747)$ & $(0.965)$ & $(0.959)$ & $(0.920)$ \\
\hline \multirow[t]{2}{*}{ 1990s period dummy } & -0.78 & $-1.20 *$ & -0.96 & -0.87 & -0.92 \\
\hline & $(0.462)$ & $(0.523)$ & $(0.769)$ & $(0.783)$ & $(0.725)$ \\
\hline \multirow[t]{2}{*}{ 2000s period dummy } & $-1.66^{* *}$ & $-2.35^{* *}$ & $-2.12^{*}$ & $-2.00 *$ & $-2.09^{* *}$ \\
\hline & $(0.532)$ & $(0.675)$ & $(0.872)$ & $(0.867)$ & $(0.695)$ \\
\hline \multirow[t]{2}{*}{ Constant } & 0.68 & 0.02 & 0.02 & -0.16 & -0.41 \\
\hline & $(0.686)$ & (1.292) & (1.405) & (1.423) & (1.188) \\
\hline Observations & 102 & 102 & 94 & 94 & 94 \\
\hline R-squared & 0.14 & 0.15 & 0.19 & 0.19 & 0.21 \\
\hline Number of countries & 21 & 21 & 21 & 21 & 21 \\
\hline Country fixed effects & Yes & Yes & Yes & Yes & Yes \\
\hline Time effects & Yes & Yes & Yes & Yes & Yes \\
\hline R-squared overall model & 0.04 & 0.01 & 0.03 & 0.03 & 0.05 \\
\hline
\end{tabular}

Now that I have established that (1) older people are more inflation averse and (2) countries with more old people have more economically orthodox political parties, two steps - which I investigate in the next section - remain. First, I need to demonstrate that the share of elderly is associated with lower 
inflation. I do so for a sample of 21 OECD countries. But OECD countries experienced ageing conjointly with other structural shifts in the economy which may be hard to fully net out using statistical methods. Focusing on OECD countries over a long period of time means most of the observations capture over time rather than cross-national variation. I therefore carry out regression analysis on a larger sample of all countries in the world for which data is available. This raises other issues of comparability between countries but ensures that the old are not spuriously related to inflation because of unobservable broader structural shifts that affected the OECD simultaneously. Both samples have strengths and shortcomings, so testing my argument on both represents a strong test.

Second, to further substantiate the causal mechanism, I show that the share of elderly is related to key economic policies (central bank independence, lower non-elderly related deficits, larger spending on old age) that affect inflation in the OECD. While this illustrates some channels through which the share of elderly affect inflation, this cannot rule out a direct effect of the elderly; for instance if they have distinct consumption patterns that generate economic effects on inflation. To investigate this latter alternative mechanism, I also test whether the share of elderly affects inflation in both democratic and nondemocratic countries: if it does, then the electoral mechanism can be shown to co-exist with other mechanisms, but if it does not, we can conclude that having a larger share of elderly only leads to lower inflation in democratic countries where they can express their preferences in the electoral arena. 


\section{Empirical tests of the determinants of inflation}

\section{Data}

To test my argument I collect data for 21 OECD countries in the period between 1960 and 2012 in the first instance. I test my argument both on this sample and on a smaller sample that ends in 2000 when controlling for central bank independence, since the common monetary policy of the ECB may introduce polarising inflation dynamics. 65 This time period allows me to test the determinants of cross-national variation in inflation both in the relatively low inflation period of post-war Europe, the high inflation episodes of the 1970s and the -very - low inflation thereafter. I initially focus on developed economies because they have more established democracies, more comparable economic structures and development levels. ${ }^{66}$

My dependent variable is the overall consumer price inflation which is most directly relevant for people's purchasing power, while my key independent variable is the share of the population that is over 65 . The latter measure of old people represents a conservative estimate of the power of the old, in the sense that it is more likely to exclude people in retirement than to include them. This seems more desirable than the reverse problem, namely including people who are still working.

All my independent variables are described in the appendix (see table A1), but two particularly important controls are Central Bank Independence (CBI)

\footnotetext{
${ }^{65}$ By removing the sanction that national central banks could impose on the sheltered sector, the European monetary union leads to polarisation between sheltered and non-sheltered sectors. Cross-national variation in inflation rates may also be affected by these polarising dynamics since countries without coordinated wage bargaining will experience greater inflationary pressures in the absence of a national central bank that can punish deviations. See Hancke 2013 and Johnston 2012 for more on this.

${ }^{66}$ Note also that it is already well known that central bank independence is not associated with inflation in developing economies. See Cukierman et al. 1992.
} 
and wage coordination. CBI can be expected to lead to lower inflation because politically motivated central banks (or government monetary policy) will not be credible in their promises not to influence electoral outcomes through opportunistic monetary policy. Many indices exist, ${ }^{67}$ but I choose to use the Cuckierman index ${ }^{68}$ partly because it is widely used and partly because the update by Polillo and Guillén has the best coverage for my time period. ${ }^{69}$ Note however that this index does not capture the ECB's monetary stance and therefore limits my sample to pre-EMU times. ${ }^{70}$ Wage coordination is important in its own right as it allows unions to internalise the effects of their wage claims - which could otherwise lead to inflation. It is also important in shaping the effectiveness of CBI: when faced with a conservative central bank, coordinated unions will internalise the response function of the central bank thereby leading to low inflation without the central bank having to raise interest rates. ${ }^{71} \mathrm{I}$ choose the wage coordination index provided by Visser which takes values between 1 (low coordination) and 5 (high coordination). ${ }^{72}$

Moreover, my baseline model controls for various economic and structural factors: GDP growth, the unemployment rate which may put downward pressure on inflation through its effect on wages, the degree of trade openness which makes inflation more costly, and the degree of deindustrialisation. I also control for political factors such as union density, which can be expected to lead to higher inflation by increasing the power of workers or to lower inflation if the olsonian effect where unions internalize the impact of their

\footnotetext{
${ }^{67}$ Alesina 1989; Bade and Parkin 1978; Cukierman, Webb, and Neyapti 1992; Eijffinger and Schaling 1993; Grilli, Masciandaro, and Tabellini 1991.

${ }^{68}$ Cuckierman 1992.

${ }^{69}$ Polillo and Guillén 2005.

${ }^{70}$ This is perhaps for the better since -as already discussed - the ECB's policy may have different effects in distinct countries and some authors have argued that unlike national central banks the ECB no longer represents a credible threat to punish excessive wage agreements. See Hancke 2013, Johnston 2012.

${ }^{71}$ See the following for a discussion of wage coordination: Franzese 1999, 2003; Hall and Franzese 1998; Iversen 1999.

72 Visser 2013.
} 
The impact of the elderly on inflation rates in developed countries

wage claims dominates. My measure of left control of the government should be associated with higher inflation. Finally, I test the effect of social expenditures and deficits. Various other factors are introduced as robustness checks and discussed with the results.

\section{Estimation strategy and results}

I include robust standard errors clustered by country to address the panel structure of my data and neutralise the biases that auto-correlation and heteroskedasticity would have on standard errors. The results for various models are shown in table 3 . In columns 1 to 3 , I include the share of the elderly with and without time and country effects. The coefficient is negative and statistically significant as expected: countries with a higher share of elderly exhibit lower levels of inflation. Next, two key economic controls are included; unemployment and real GDP growth again with and without country and time effects (columns 4 to 6 ). In columns 7 to 10 , I include deficits, trade openness, and the share of the labour force in industry. The share of elderly remains negatively associated with inflation, real GDP growth is also negatively associated with inflation, while unemployment and openness have no statistically significant effect. Columns 11 to 19 include the left control of the government (no effect ${ }^{73}$ ), union density (positive effect), spending on social security (no effect), central bank independence (negative effect) and the wage coordination index (no effect). ${ }^{74}$ In column 18, all independent variables are normalised so as to simplify interpretation of magnitude: a 1 standard deviation change in the share of the elderly has a

\footnotetext{
${ }^{73}$ By no effect I mean that the effect is not statistically significant, by positive I mean the coefficient is positive and statistically significant and by negative that it is negative and statistically significant.

${ }^{74}$ Note that there are more columns that new variables because some columns show the effect with and without country fixed effects for robustness.
} 
much greater impact on inflation than either central bank independence or wage coordination. Throughout the effect of the share of elderly on inflation stays stable, negative, and statistically significant.

One could argue at this stage that this correlation might nevertheless be spurious for two reasons. One reason is that the correlation between the share of the old and inflation might be driven by the concomitance of high inflation and low share of elderly in 1970s and low inflation and high share of elderly in 2000s. But if this is was the case, restricting sample to post-1980 or post1990 periods would result in a non-significant impact of elderly on inflation. Yet, statistical significance remains for the coefficient of elderly when restricting the analysis to more recent periods (see table A4 in appendix).

The other reason the correlation might be spurious is because the share of the elderly does not itself affect inflation, but instead influences policies that affect inflation. The previous section's analysis of party manifesto data partly addresses this issue, but it may be that both inflation and the share of elderly are trending upwards and that the share of elderly has in fact no effect on any factors that may in turn determine inflation. The Fisher's test rejects the null hypothesis that all panel series are non-stationary for inflation but does not reject the null hypothesis for the share of elderly. Spurious relationships between two variables arising from co-integration is unlikely to occur when only one of the two variables is non-stationary, but I nevertheless test the effect of the elderly on the first difference in inflation in columns (1) and (2) in table 4 on a model that includes a lagged dependent variable to neutralise the effect of the level of inflation prior to its change. Columns (1) and (2) show that a higher share of elderly (3 years moving average since the effect cannot be expected to occur instantaneously, not lagged in column 1 and lagged in column 2) are negatively associated with the first difference in inflation. In 
columns 3 to 6 , I turn my attention to the effect of elderly on other dependent variables that may themselves affect inflation: column (3) shows that the share of elderly is positively associated with the level of $\mathrm{CBI}^{75}$, column (4) that countries with more elderly spend more on old age, and column (5) that the share of elderly is negatively associated with higher non-old ${ }^{76}$ related deficits. Note that all independent variables are normalised so as to simplify interpretation of magnitude: this shows that a 1 standard deviation change in the share of the elderly has a much greater impact on central bank independence than other independent variables.

Though my estimation strategy is unlikely to be biased, I rerun my model using several alternative estimation methods in table 5: a generalized linear models that allows me to specify the within-group correlation structure for the panels, ${ }^{77}$ a feasible generalized least squares, ${ }^{78}$ and a panel-corrected standard error model ${ }^{79}$. The results concerning the share of the elderly are unchanged. Next, I turn my attention to the likelihood of having particularly high inflation by running a binary logistic model with robust clustered standard errors on a dependent variable that takes value 1 if inflation is high (defined here as being above 10\%) and 0 otherwise. Having a large share of elderly significantly reduces the probability of having a high inflation episode, consistent with the notion that high inflation incurs too high an electoral penalty in countries with large shares of elderly.

\footnotetext{
75 In table A5 in the appendix, I run an analysis of the determinants of CBI with and without time and country effects, and also run a logistic model where the dependent variable takes value 1 if there was an increase in CBI and 0 otherwise. The results suggest the share of elderly are positively associated with higher CBI and makes an increase in CBI index more likely.

${ }^{76}$ I.e. when 'neutralising' the effect of spending on old age by substracting spending on old age from deficits which creates a deficit variable that is not driven by spending on old age.

77 Using the xtgee in stata and specifying a Gaussian family, an identity link and an autoregressive (ar1) error process.

78 Using the xtgls command in stata.

${ }^{79}$ Using the xtpcse command in stata and specifying an ar1 process.
} 
In table 6, I test my argument in years where elections were held (column 1) and where they were not (column 2). It is plausible that being a member of the EMU has an effect of inflation so I include a non-EMU dummy in column (3) that takes value 0 if the country is a member of the Eurozone and 1 if it is not a member of the Eurozone. Being outside EMU is not statistically significant. Employment protection legislation and bargaining coverage both have a positive associations with inflation (columns 4 and 5), while union authority and union concentration have no effect (columns 6 and 7). The influential literature on Varieties of Capitalism suggests there may be systematic differences between Liberal Market Economies and Coordinated Market Economies in terms of economic outcomes. ${ }^{80} \mathrm{I}$ therefore include an LME dummy in column 8 which is not statistically significant. I also check whether including the size of the stock market (column 9) makes a difference. As expected, the size of stock markets as \% of GDP is negatively correlated with inflation. Throughout my key results concerning the effect of the elderly share on inflation remains.

Moreover, I carry out additional robustness checks which for reasons of space are shown in the appendix (table A3). In column 1, I include a lagged dependent variable in the baseline model discussed earlier (which is positive and statistically significant). In columns 2 and 3, I check that lagging all independent variables (with and without country fixed effects, respectively) does not change the sign or statistical significance of the coefficient for the share of elderly. In columns 4 to 13, I check the robustness of my results for several additional independent variables (with and without fixed effects for each independent variable). Capital openness (columns 4 and 5) is negative and significant suggesting that capital mobility lowers inflation rates. Structural unemployment has no effect (columns 6 and 7), the share of home

\footnotetext{
${ }^{80}$ Hall and Soskice 2001.
} 
The impact of the elderly on inflation rates in developed countries

ownership is positive and significant only when no fixed effects are included (columns 8 and 9), and the share of employment in the industry (columns 10 and 11) has no statistically significant effect on inflation. In columns 12 and 13 , I test the effect of including a longer time series of employment protection legislation (EPL) developed by Allard (2005). ${ }^{81}$ The results suggest that higher EPL only has a positive statistically significant effect when country fixed effects are not included. Throughout, the effect of the share of the elderly on inflation is negative and statistically significant.

Finally, the analysis so far has documented a link between the share of elderly and party manifestos, between the share of elderly and central bank independence, and between the share of elderly and inflation, but not between party manifestos and central bank independence. This is addressed in table A6 in the appendix: I run several regressions on decade's averages for 21 OECD from 1960s to 2000s (ie there are 5 time periods) that show the share of elderly are positively associated with economic orthodoxy of party manifestos (column 1), while the share of elderly and economic orthodoxy (both lagged one period) are positively associated with higher central bank independence (column 2).

${ }^{81}$ Note I had already tested the effect of the EPL index developed by the OECD that was only available from 1985 onwards. 
Table 3: The determinants of cross-national variation in inflation levels

\begin{tabular}{|c|c|c|c|c|c|c|c|c|c|c|}
\hline Column & $(1)$ & $(2)$ & (3) & (4) & (5) & (6) & (7) & $(8)$ & (9) & $(10)$ \\
\hline $\begin{array}{l}\text { Dependent } \\
\text { variable }\end{array}$ & \multicolumn{10}{|c|}{ Level of Consumer Price Inflation } \\
\hline Elderly & $\begin{array}{c}-0.56^{* * *} \\
(0.059)\end{array}$ & $\begin{array}{c}-0.26^{*} \\
(0.112)\end{array}$ & $\begin{array}{c}-0.27^{*} \\
(0.119)\end{array}$ & $\begin{array}{c}-0.78^{* * *} \\
(0.105)\end{array}$ & $\begin{array}{l}-0.33^{* *} \\
(0.119)\end{array}$ & $\begin{array}{c}-0.80^{* * *} \\
(0.113)\end{array}$ & $\begin{array}{c}-0.82^{* * *} \\
(0.148)\end{array}$ & $\begin{array}{c}-0.85^{* * *} \\
(0.168)\end{array}$ & $\begin{array}{l}-0.57^{* *} \\
(0.196)\end{array}$ & $\begin{array}{l}-0.57^{*} \\
(0.249)\end{array}$ \\
\hline $\begin{array}{l}\text { Real GDP } \\
\text { growth }\end{array}$ & & & & $\begin{array}{l}-0.51^{* * *} \\
(0.106)\end{array}$ & $\begin{array}{l}-0.28^{* *} \\
(0.104)\end{array}$ & $\begin{array}{l}-0.53^{* * *} \\
(0.110)\end{array}$ & $\begin{array}{l}-0.45^{* * *} \\
(0.126)\end{array}$ & $\begin{array}{l}-0.48^{* *} \\
(0.132)\end{array}$ & $\begin{array}{l}-0.49^{* * *} \\
(0.107)\end{array}$ & $\begin{array}{l}-0.50^{* * *} \\
(0.115)\end{array}$ \\
\hline $\begin{array}{l}\text { Unemployment } \\
\text { rate }\end{array}$ & & & & -0.14 & $-0.21^{*}$ & -0.16 & $-0.22^{* *}$ & $-0.24^{*}$ & -0.08 & -0.10 \\
\hline Deficit & & & & $(0.080)$ & $(0.105)$ & $(0.088)$ & $\begin{array}{c}(0.083) \\
-0.18^{* * *} \\
(0.054)\end{array}$ & $\begin{array}{l}(0.090) \\
-0.18^{* *} \\
(0.055)\end{array}$ & $\begin{array}{c}(0.069) \\
-0.16^{* *} \\
(0.060) \\
0.02\end{array}$ & $\begin{array}{c}(0.073) \\
-0.16^{*} \\
(0.061) \\
0.04\end{array}$ \\
\hline $\begin{array}{l}\text { Trade } \\
\text { openness }\end{array}$ & & & & & & & & & $\begin{array}{c}0.02 \\
(0.027)\end{array}$ & $\begin{array}{c}0.04 \\
(0.049)\end{array}$ \\
\hline $\begin{array}{l}\text { Industrial } \\
\text { employment }\end{array}$ & & & & & & & & & $\begin{array}{l}32.55^{* * *} \\
(6.914)\end{array}$ & $\begin{array}{l}35.98^{* * *} \\
(9.263)\end{array}$ \\
\hline Constant & $\begin{array}{c}12.53^{* * *} \\
(0.944)\end{array}$ & $\begin{array}{l}4.39 * * * \\
(1.086)\end{array}$ & $\begin{array}{l}4.47^{* * *} \\
(1.130)\end{array}$ & $\begin{array}{c}17.88^{* * *} \\
(1.671)\end{array}$ & $\begin{array}{l}7.56^{* * *} \\
(1.502)\end{array}$ & $\begin{array}{c}18.34^{* * *} \\
(1.382)\end{array}$ & $\begin{array}{c}18.85^{* * *} \\
(2.293)\end{array}$ & $\begin{array}{c}19.57^{* * *} \\
(2.144)\end{array}$ & $\begin{array}{c}3.50 \\
(3.100)\end{array}$ & $\begin{array}{c}1.70 \\
(4.851)\end{array}$ \\
\hline Observations & 1,110 & 1,110 & 1,110 & 1,092 & 1,092 & 1,092 & 981 & 981 & 959 & 959 \\
\hline $\begin{array}{l}\text { Number of } \\
\text { countries }\end{array}$ & 21 & 21 & 21 & 21 & 21 & 21 & 21 & 21 & 21 & 21 \\
\hline $\begin{array}{l}\text { Country Fixed } \\
\text { effects }\end{array}$ & No & No & Yes & No & No & Yes & No & Yes & No & Yes \\
\hline Year effects & No & Yes & Yes & No & Yes & No & No & No & No & No \\
\hline $\begin{array}{l}\text { R-squared } \\
\text { within model }\end{array}$ & 0.11 & 0.65 & 0.65 & 0.21 & 0.67 & 0.21 & 0.27 & 0.27 & 0.35 & 0.35 \\
\hline $\begin{array}{l}\text { R-squared } \\
\text { overall model }\end{array}$ & 0.08 & 0.56 & 0.56 & 0.12 & 0.53 & 0.12 & 0.14 & 0.14 & 0.20 & 0.18 \\
\hline $\begin{array}{l}\text { R-squared } \\
\text { between model }\end{array}$ & 0.02 & 0.01 & 0.01 & 0.00 & 0.11 & 0.01 & 0.04 & 0.05 & 0.02 & 0.04 \\
\hline
\end{tabular}
Note: Robust standard errors clustered by country in parentheses; ${ }^{* * *} p<0.001,{ }^{* *} p<0.01$, * $p<0.05$. 
The impact of the elderly on inflation rates in developed countries

Table 3(continued): The determinants of cross-national variation in inflation levels

\begin{tabular}{|c|c|c|c|c|c|}
\hline Column & (11) & (12) & (13) & (14) & (15) \\
\hline $\begin{array}{l}\text { Dependent } \\
\text { variable }\end{array}$ & \multicolumn{5}{|c|}{ Level of Consumer Price Inflation } \\
\hline \multirow[t]{2}{*}{ Elderly } & $-0.61^{* *}$ & $-0.61 *$ & $-0.62^{* * *}$ & $-0.60 * * *$ & $-0.63^{* *}$ \\
\hline & $(0.204)$ & $(0.243)$ & $(0.173)$ & $(0.170)$ & $(0.210)$ \\
\hline \multirow[t]{2}{*}{ Real GDP growth } & $-0.46^{* * *}$ & $-0.47^{* * *}$ & $-0.43^{* * *}$ & $-0.43^{* * *}$ & $-0.44^{* * *}$ \\
\hline & $(0.100)$ & $(0.106)$ & $(0.084)$ & $(0.090)$ & $(0.092)$ \\
\hline \multirow{2}{*}{$\begin{array}{l}\text { Unemployment } \\
\text { rate }\end{array}$} & -0.11 & -0.13 & $-0.23^{* *}$ & $-0.22^{*}$ & $-0.33^{*}$ \\
\hline & $(0.079)$ & $(0.086)$ & $(0.071)$ & $(0.108)$ & $(0.120)$ \\
\hline \multirow[t]{2}{*}{ Deficit } & $-0.17^{* *}$ & $-0.17^{*}$ & $-0.18^{* * *}$ & $-0.19 * *$ & $-0.17^{* *}$ \\
\hline & $(0.058)$ & $(0.060)$ & $(0.054)$ & $(0.057)$ & $(0.059)$ \\
\hline \multirow[t]{2}{*}{ Trade openness } & 0.02 & 0.03 & 0.02 & 0.02 & 0.04 \\
\hline & $(0.030)$ & $(0.047)$ & $(0.023)$ & $(0.025)$ & $(0.034)$ \\
\hline \multirow[t]{2}{*}{ Industry } & $30.65^{* * *}$ & $32.57^{* *}$ & $16.41^{*}$ & $16.30^{*}$ & 12.93 \\
\hline & $(6.900)$ & $(8.716)$ & $(6.998)$ & $(6.996)$ & $(8.122)$ \\
\hline \multirow{2}{*}{ Left government } & 0.01 & 0.01 & 0.01 & 0.01 & 0.01 \\
\hline & $(0.005)$ & $(0.005)$ & $(0.004)$ & $(0.004)$ & $(0.004)$ \\
\hline \multirow{2}{*}{ Union density } & & & $0.13^{* *}$ & $0.14^{* *}$ & $0.19^{* *}$ \\
\hline & & & $(0.045)$ & $(0.046)$ & $(0.061)$ \\
\hline \multirow[t]{2}{*}{ Social security } & & & & -0.05 & -0.02 \\
\hline & & & & $(0.185)$ & $(0.217)$ \\
\hline \multirow[t]{2}{*}{ Constant } & 4.56 & 3.53 & 4.88 & 4.89 & 3.00 \\
\hline & (3.571) & $(4.869)$ & (3.828) & (3.819) & $(4.622)$ \\
\hline Observations & 939 & 939 & 917 & 917 & 917 \\
\hline $\begin{array}{l}\text { Number of } \\
\text { countries }\end{array}$ & 21 & 21 & 21 & 21 & 21 \\
\hline $\begin{array}{l}\text { Country fixed } \\
\text { effects }\end{array}$ & No & Yes & No & No & Yes \\
\hline Year effects & No & No & No & No & No \\
\hline R-squared within & 0.35 & 0.35 & 0.44 & 0.44 & 0.45 \\
\hline R-squared overall & 0.21 & 0.19 & 0.17 & 0.16 & 0.11 \\
\hline R-squared btw & 0.06 & 0.08 & 0.02 & 0.02 & 0.02 \\
\hline
\end{tabular}


Table 3 (continued): The determinants of cross-national variation in inflation levels

\begin{tabular}{|c|c|c|c|}
\hline Column & $(16)$ & $(17)$ & $(18)$ \\
\hline Dependent variable & \multicolumn{3}{|c|}{ Level of Consumer Price Inflation } \\
\hline \multirow[t]{2}{*}{ Elderly } & $-0.60 *$ & $-0.59^{*}$ & $-1.80^{*}$ \\
\hline & $(0.269)$ & $(0.270)$ & $(0.815)$ \\
\hline \multirow[t]{2}{*}{ Real GDP growth } & $-0.70^{* * *}$ & $-0.69 * * *$ & $-1.92^{* * *}$ \\
\hline & $(0.068)$ & $(0.070)$ & $(0.196)$ \\
\hline \multirow{2}{*}{ Unemployment rate } & $-0.41^{* * *}$ & $-0.41^{* * *}$ & $-1.65^{* * *}$ \\
\hline & $(0.109)$ & $(0.112)$ & $(0.452)$ \\
\hline \multirow[t]{2}{*}{ Deficit } & $-0.31^{* * *}$ & $-0.32^{* * *}$ & $-1.13^{* * *}$ \\
\hline & $(0.089)$ & $(0.093)$ & $(0.328)$ \\
\hline \multirow[t]{2}{*}{ Trade openness } & $0.10^{* * *}$ & $0.09 * * *$ & $2.80 * * *$ \\
\hline & $(0.022)$ & $(0.024)$ & $(0.740)$ \\
\hline \multirow[t]{2}{*}{ Industry } & 9.59 & 8.35 & 0.60 \\
\hline & $(8.105)$ & $(7.699)$ & $(0.550)$ \\
\hline \multirow[t]{2}{*}{ Left government } & $0.01 *$ & $0.01^{*}$ & $0.33^{*}$ \\
\hline & $(0.004)$ & $(0.004)$ & $(0.149)$ \\
\hline \multirow[t]{2}{*}{ Union density } & $0.17^{* * *}$ & $0.16^{* * *}$ & $3.24^{* * *}$ \\
\hline & $(0.046)$ & $(0.047)$ & $(0.934)$ \\
\hline \multirow[t]{2}{*}{ Social security } & -0.19 & -0.19 & -0.76 \\
\hline & $(0.205)$ & $(0.203)$ & $(0.825)$ \\
\hline \multirow[t]{2}{*}{ CBI } & $-4.33^{* *}$ & $-4.38^{* *}$ & $-0.83^{* *}$ \\
\hline & $(1.443)$ & $(1.438)$ & $(0.273)$ \\
\hline \multirow[t]{2}{*}{ Coordination index } & & 0.21 & 0.28 \\
\hline & & $(0.206)$ & $(0.280)$ \\
\hline \multirow{2}{*}{ Constant } & 7.20 & 7.31 & $6.56^{* * *}$ \\
\hline & $(5.308)$ & $(5.117)$ & $(1.219)$ \\
\hline Observations & 699 & 699 & 699 \\
\hline $\begin{array}{l}\text { Number of } \\
\text { countries }\end{array}$ & 21 & 21 & 21 \\
\hline $\begin{array}{l}\text { Country fixed } \\
\text { effects }\end{array}$ & No & No & No \\
\hline Year effects & No & No & No \\
\hline R-squared within & 0.52 & 0.53 & 0.53 \\
\hline R-squared overall & 0.10 & 0.09 & 0.09 \\
\hline R-squared btw & 0.03 & 0.03 & 0.03 \\
\hline
\end{tabular}


The impact of the elderly on inflation rates in developed countries

Table 4: Alternative dependent variables

\begin{tabular}{|c|c|c|c|c|c|}
\hline Column & $(1)$ & $(2)$ & $(3)$ & $(4)$ & (5) \\
\hline Dependent variable & \multicolumn{2}{|c|}{$\begin{array}{c}\text { Inflation } \\
\text { (first difference) }\end{array}$} & CBI & $\begin{array}{l}\text { Spending } \\
\text { on old age }\end{array}$ & $\begin{array}{l}\text { Deficit-minus } \\
\text { Spending on } \\
\text { old age }\end{array}$ \\
\hline $\begin{array}{l}\text { Independent variable } \\
\text { standardised }\end{array}$ & No & No & Yes & Yes & Yes \\
\hline $\begin{array}{l}\text { Inflation } \\
\text { (lagged) }\end{array}$ & $\begin{array}{l}-0.14^{* * *} \\
(0.030)\end{array}$ & $\begin{array}{l}-0.14^{* * *} \\
(0.031)\end{array}$ & & & \\
\hline $\begin{array}{l}\text { Elderly } \\
\text { ( } 3 \text { years moving average) }\end{array}$ & $\begin{array}{l}-0.06^{t} \\
(0.031)\end{array}$ & & $\begin{array}{c}0.12^{* *} \\
(0.036)\end{array}$ & $\begin{array}{l}1.36^{* * *} \\
(0.205)\end{array}$ & $\begin{array}{c}-2.06^{t} \\
(1.131)\end{array}$ \\
\hline $\begin{array}{l}\text { Elderly } \\
\text { ( } 3 \text { years moving average, } \\
\text { lagged once) }\end{array}$ & & $\begin{array}{l}-0.07^{*} \\
(0.032)\end{array}$ & & & \\
\hline Real GDP & $\begin{array}{c}0.02 \\
(0.050)\end{array}$ & $\begin{array}{c}0.02 \\
(0.052)\end{array}$ & $\begin{array}{c}0.004 \\
(0.004)\end{array}$ & $\begin{array}{c}-0.03 \\
(0.082)\end{array}$ & $\begin{array}{c}1.11^{*} \\
(0.404)\end{array}$ \\
\hline Unemployment rate & $\begin{array}{l}-0.08^{* *} \\
(0.026)\end{array}$ & $\begin{array}{l}-0.08^{* *} \\
(0.026)\end{array}$ & $\begin{array}{c}0.04^{*} \\
(0.019)\end{array}$ & $\begin{array}{c}0.12 \\
(0.175)\end{array}$ & $\begin{array}{l}-1.33^{*} \\
(0.529)\end{array}$ \\
\hline Trade openness & $\begin{array}{c}0.00^{* *} \\
(0.002)\end{array}$ & $\begin{array}{l}0.0040^{*} \\
(0.002)\end{array}$ & $\begin{array}{c}0.03 \\
(0.031)\end{array}$ & $\begin{array}{l}-0.57^{* * *} \\
(0.162)\end{array}$ & $\begin{array}{c}0.82 \\
(1.610)\end{array}$ \\
\hline Industrial employment & $\begin{array}{c}3.81 \\
(2.018)\end{array}$ & $\begin{array}{c}4.00 \\
(2.088)\end{array}$ & $\begin{array}{c}0.01 \\
(0.029)\end{array}$ & $\begin{array}{c}-0.67 \\
(0.441)\end{array}$ & $\begin{array}{c}2.90 \\
(1.724)\end{array}$ \\
\hline Left government & $\begin{array}{l}0.0013 \\
(0.001)\end{array}$ & $\begin{array}{l}0.0014 \\
(0.001)\end{array}$ & $\begin{array}{l}-0.003 \\
(0.008)\end{array}$ & $\begin{array}{c}-0.002 \\
(0.071)\end{array}$ & $\begin{array}{c}-0.08 \\
(0.239)\end{array}$ \\
\hline Union density & $\begin{array}{l}-0.0008 \\
(0.004)\end{array}$ & $\begin{array}{l}-0.0005 \\
(0.004)\end{array}$ & $\begin{array}{c}-0.01 \\
(0.018)\end{array}$ & $\begin{array}{c}0.38 \\
(0.434)\end{array}$ & $\begin{array}{c}1.51 \\
(1.229)\end{array}$ \\
\hline Deficit & $\begin{array}{l}0.0032 \\
(0.027)\end{array}$ & $\begin{array}{c}0.01 \\
(0.028)\end{array}$ & $\begin{array}{c}0.02 \\
(0.013)\end{array}$ & & \\
\hline Social transfers & & & $\begin{array}{l}-0.07^{*} \\
(0.027)\end{array}$ & $\begin{array}{c}0.50 \\
(0.278)\end{array}$ & \\
\hline Coordination index & & & $\begin{array}{c}0.01 \\
(0.013)\end{array}$ & $\begin{array}{c}0.06 \\
(0.111)\end{array}$ & \\
\hline CBI & & & & $\begin{array}{c}0.14 \\
(0.084)\end{array}$ & \\
\hline Constant & $\begin{array}{c}0.39 \\
(0.566)\end{array}$ & $\begin{array}{c}0.50 \\
(0.598)\end{array}$ & $\begin{array}{l}0.43^{* * *} \\
(0.033)\end{array}$ & $\begin{array}{l}6.20^{* * *} \\
(0.362)\end{array}$ & $\begin{array}{c}-9.15^{* * *} \\
(0.966)\end{array}$ \\
\hline $\begin{array}{l}\text { Observations } \\
\text { R-squared }\end{array}$ & 916 & 906 & 678 & 424 & $\begin{array}{l}598 \\
0.46\end{array}$ \\
\hline Number of countries & 21 & 21 & 21 & 21 & 21 \\
\hline Country fixed effects & No & No & No & No & No \\
\hline Year effects & No & No & No & No & No \\
\hline R-squared within model & 0.17 & 0.17 & 0.31 & 0.59 & 0.46 \\
\hline R-squared overall model & 0.13 & 0.13 & 0.06 & 0.48 & 0.30 \\
\hline R-squared between model & 0.35 & 0.31 & 0.01 & 0.45 & 0.12 \\
\hline
\end{tabular}
Note: Robust standard errors clustered by country in parentheses; ${ }^{* *} p<0.001,{ }^{* *} p<0.01,{ }^{*}$ $p<0.05 ;{ }^{t} p<0.1$. 
Table 5: Alternative estimation methods

\begin{tabular}{|c|c|c|c|c|}
\hline Column & (1) & (2) & (3) & $(4)$ \\
\hline Dependent variable & \multicolumn{3}{|c|}{ Level of Consumer Price Inflation } & $\begin{array}{c}\text { Binary high inflation } \\
\text { dummy }\end{array}$ \\
\hline Method & XTGEE & XTGLS & XTPCSE & Logit \\
\hline Elderly & $\begin{array}{l}-0.56^{*} \\
(0.258)\end{array}$ & $\begin{array}{c}-0.44^{* * *} \\
(0.079)\end{array}$ & $\begin{array}{l}-0.42^{* * *} \\
(0.104)\end{array}$ & $\begin{array}{l}-0.23^{* *} \\
(0.078)\end{array}$ \\
\hline Real GDP growth & $\begin{array}{l}-0.39 * * * \\
(0.036)\end{array}$ & $\begin{array}{l}-0.58^{* * *} \\
(0.077)\end{array}$ & $\begin{array}{l}-0.38^{* * *} \\
(0.029)\end{array}$ & $\begin{array}{l}-0.34^{* * *} \\
(0.064)\end{array}$ \\
\hline Unemployment rate & $\begin{array}{l}-0.34^{* * *} \\
(0.091)\end{array}$ & $\begin{array}{c}-0.03 \\
(0.049)\end{array}$ & $\begin{array}{l}-0.18^{* *} \\
(0.057)\end{array}$ & $\begin{array}{c}-0.04 \\
(0.060)\end{array}$ \\
\hline Deficit & $\begin{array}{c}0.07 \\
(0.053)\end{array}$ & $\begin{array}{c}-0.32^{* * *} \\
(0.061)\end{array}$ & $\begin{array}{c}0.02 \\
(0.040)\end{array}$ & $\begin{array}{l}-0.20^{*} \\
(0.092)\end{array}$ \\
\hline Trade openness & $\begin{array}{l}0.10^{* * *} \\
(0.017)\end{array}$ & $\begin{array}{c}0.01^{*} \\
(0.007)\end{array}$ & $\begin{array}{l}0.04^{* * *} \\
(0.008)\end{array}$ & $\begin{array}{c}0.00 \\
(0.009)\end{array}$ \\
\hline Industrial employment & $\begin{array}{l}28.27^{* *} \\
(9.308)\end{array}$ & $\begin{array}{c}18.40^{* * *} \\
(3.385)\end{array}$ & $\begin{array}{c}20.68^{* * *} \\
(4.076)\end{array}$ & $\begin{array}{c}7.97 \\
(6.080)\end{array}$ \\
\hline Union density & $\begin{array}{c}-0.01 \\
(0.030)\end{array}$ & $\begin{array}{l}0.05^{* * *} \\
(0.011)\end{array}$ & $\begin{array}{c}0.01 \\
(0.011)\end{array}$ & $\begin{array}{c}0.03^{*} \\
(0.013)\end{array}$ \\
\hline CBI & $\begin{array}{l}-1.20 \\
(1.277)\end{array}$ & $\begin{array}{c}-3.19^{* * *} \\
(0.940)\end{array}$ & $\begin{array}{l}-1.95^{*} \\
(0.843)\end{array}$ & $\begin{array}{c}-2.13 \\
(1.868)\end{array}$ \\
\hline Coordination index & $\begin{array}{c}-0.05 \\
(0.124)\end{array}$ & $\begin{array}{c}-0.47^{* * *} \\
(0.141)\end{array}$ & $\begin{array}{l}-0.14^{*} \\
(0.070)\end{array}$ & $\begin{array}{c}-0.30^{*} \\
(0.141)\end{array}$ \\
\hline Constant & $\begin{array}{c}2.02 \\
(4.996) \\
\end{array}$ & $\begin{array}{l}7.54^{* * *} \\
(1.545)\end{array}$ & $\begin{array}{l}5.46^{* * *} \\
(1.596)\end{array}$ & $\begin{array}{c}0.10 \\
(2.186)\end{array}$ \\
\hline $\begin{array}{l}\text { Observations } \\
\text { Number of countries } \\
\text { R-squared } \\
\text { Details }\end{array}$ & $\begin{array}{c}699 \\
21 \\
\text { n.a. } \\
\text { fam(gaus) } \\
\text { link(iden) } \\
\text { corr(ar1) }\end{array}$ & $\begin{array}{c}699 \\
21 \\
\text { n.a. }\end{array}$ & $\begin{array}{c}699 \\
21 \\
0.19 \\
\text { correlation(a } \\
\text { r1) }\end{array}$ & $\begin{array}{c}699 \\
21 \\
\text { Pseudo (0.2004) } \\
\text { vce(cluster id) }\end{array}$ \\
\hline
\end{tabular}


The impact of the elderly on inflation rates in developed countries

Table 6: Alternative samples and additional independent variables

\begin{tabular}{lcccc}
\hline Column & $(1)$ & $(2)$ & $(3)$ & $(4)$ \\
\hline Elderly & $-0.66^{* * *}$ & $-0.55^{*}$ & $-0.59^{* *}$ & $-0.48^{*}$ \\
Real GDP growth & $-0.65^{* * *}$ & $-0.71^{* * *}$ & $-0.68^{* * *}$ & -0.10 \\
Unemployment rate & $-0.27^{* *}$ & $-0.37^{* * *}$ & $-0.38^{* * *}$ & $-0.26^{* *}$ \\
Deficit & $-0.37^{* * *}$ & $-0.31^{* * *}$ & $-0.32^{* * *}$ & -0.06 \\
Trade openness & $0.05^{* *}$ & $0.08^{* * *}$ & $0.08^{* * *}$ & 0.00 \\
Industrial employment & 8.63 & 12.18 & 9.50 & 14.04 \\
Left government & 0.01 & $0.01^{*}$ & $0.01^{* *}$ & -0.00 \\
Union density & $0.10^{* *}$ & $0.15^{* * *}$ & $0.15^{* * *}$ & $0.07^{*}$ \\
Social transfers & -0.11 & -0.21 & -0.18 & \\
CBI & $-3.62^{*}$ & $-4.03^{* * *}$ & $-4.31^{* * *}$ & \\
Coordination & -0.11 & 0.28 & 0.19 & \\
Non-EMU dummy & & & -0.17 & \\
EPL & $11.28^{* *}$ & 6.30 & 8.84 & $2.60^{* * *}$ \\
\hline Constant & 218 & 481 & 699 & 544 \\
Observations & 21 & 21 & 21 & 21 \\
Number of countries & Election & Non-election & No & No \\
Sub-sample & years only & years only & & \\
& No & No & No & No \\
Country fixed effects & No & No & No & No \\
Time effects & 0.48 & 0.53 & 0.52 & 0.39 \\
R-squared within model & 0.17 & 0.10 & 0.12 & 0.10 \\
R-squared overall model & 0.02 & 0.04 & 0.01 & 0.01 \\
R-squared between & & & & \\
model & & & \\
\hline
\end{tabular}

Note: Robust standard errors clustered by country in parentheses; ${ }^{* * *} p<0.01,{ }^{* *} p<0.05,{ }^{*}$ $p<0.1$. 
Table 6 (continued): Alternative samples and additional independent variables

\begin{tabular}{lccccc}
\hline Column & $(5)$ & $(6)$ & $(7)$ & $(8)$ & $(9)$ \\
\hline Elderly & $-0.63^{* * *}$ & $-0.49^{*}$ & $-0.51^{*}$ & $-0.60^{* *}$ & $-0.74 \mathrm{t}$ \\
Real GDP growth & $-0.46^{* * *}$ & $-0.67^{* * *}$ & $-0.68^{* * *}$ & $-0.70^{* * *}$ & $-0.27^{* *}$ \\
Unemployment rate & -0.08 & $-0.53^{* * *}$ & $-0.54^{* * *}$ & $-0.42^{* * *}$ & $-0.55^{* * *}$ \\
Deficit & -0.06 & $-0.32^{* * *}$ & $-0.33^{* * *}$ & $-0.31^{* * *}$ & 0.02 \\
Trade openness & 0.00 & $0.12^{* * *}$ & $0.13^{* * *}$ & $0.10^{* * *}$ & 0.04 \\
Industrial employment & $22.83^{* * *}$ & 16.25 & 11.40 & 9.37 & 15.78 \\
Left government & 0.00 & $0.01^{* *}$ & $0.01^{* * *}$ & $0.01^{* *}$ & -0.01 \\
Union density & & $0.18^{* * *}$ & $0.19^{* * *}$ & $0.17^{* * *}$ & $0.18^{* *}$ \\
Social transfers & & -0.15 & -0.18 & -0.19 & 0.10 \\
CBI & & $-3.45^{*}$ & $-3.94^{* *}$ & $-4.38^{* * *}$ & -0.75 \\
Bargaining coverage & $0.03^{*}$ & & & & \\
Union authority & & -5.41 & & & \\
Union concentration & & & -3.21 & & \\
LME dummy & & & & 0.09 & \\
Size of stock market & & & & 7.10 & 5.13 \\
\hline Constant & $6.33^{* * *}$ & 2.74 & 3.24 & 699 & 264 \\
Observations & 376 & 649 & 636 & 21 & 21 \\
Number of countries & 21 & 21 & 21 & No & No \\
Sub-sample & No & No & No & No & No \\
Country fixed effects & No & Yes & Yes & No & No \\
Time effects & No & No & No & 0.53 & 0.65 \\
R-squared within & 0.39 & 0.52 & 0.51 & & \\
model & & & & 0.09 & 0.0034 \\
R-squared overall & 0.31 & 0.11 & 0.08 & & \\
model & & & & & 0.07 \\
R-squared between & 0.02 & 0.00 & 0.03 & & \\
model & & & & & \\
\hline Note: Robust standar & & & & & \\
\hline
\end{tabular}

Note: Robust standard errors clustered by country in parentheses; ${ }^{* * *} p<0.01,{ }^{* *} p<0.05,{ }^{*}$ $p<0.1$. 
The impact of the elderly on inflation rates in developed countries

\section{Dynamics of adjustments: Error Correction Model}

So far my results show that there is a robust association between the share of elderly and inflation, but say little about the dynamics of adjustment. It is for instance implausible that an increase in the share of elderly between time $t$ and time $t+1$ results only or necessarily result in a change in inflation in say time $\mathrm{t}+2$. To give a clearer sense of dynamics and as a final robustness check on the effect of the elderly on inflation in OECD countries, I estimate a single equation Error Correction Model (ECM) of the standard form: $\Delta$ Inflation $_{\mathrm{i}, \mathrm{t}}=\alpha$ $+\beta_{1} \Delta$ Elderly $_{\mathrm{i}, \mathrm{t}}+\beta_{2}$ Inflation $_{\mathrm{i}, \mathrm{t}-1}+\beta_{3}$ Elderly $_{\mathrm{i}, \mathrm{t}-1}+\sum \mathrm{k}_{\mathrm{j}}^{*}$ Controls $_{\mathrm{j}, \mathrm{i}, \mathrm{t}} ;$ which can be

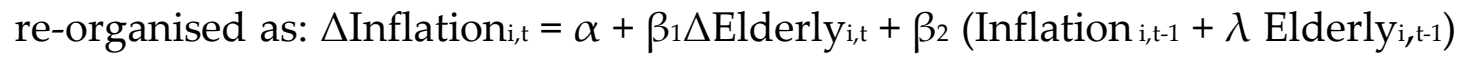
$+\sum \mathrm{k}_{\mathrm{j}}^{*}$ Controls $\mathrm{j}, \mathrm{i}, \mathrm{t}$; where $\beta_{1}$ is the short run immediate response of inflation to a rise in the share elderly and $\lambda$ is the long run response and calculated as $\beta_{2}$ * $\lambda=\beta_{3} \Leftrightarrow \lambda=\beta_{3} / \beta_{2}$. I include country fixed effects to account for unobserved country heterogeneity.

Column 1 in Table 7 shows that the results for the ECM are as follows: $\Delta$ Inflation $_{\mathrm{i}, \mathrm{t}}=-0.95+0.9 \Delta$ Elderly $_{\mathrm{i}, \mathrm{t}}-0.22$ Inflation $_{\mathrm{i}, \mathrm{t}-\mathrm{-}-0} 0.05$ Elderly $_{\mathrm{i}, \mathrm{t}-1} \ldots ;$ which can be rewritten as: $\Delta$ Inflation $_{\mathrm{i}, \mathrm{t}}=-0.95+0.9 \Delta$ Elderly $_{\mathrm{i}, \mathrm{t}}-0.22\left(\right.$ Inflation $_{\mathrm{i}, \mathrm{t}-\mathrm{1}}+$ 0.21 Elderlyi,t-1) ...; where 0.9 is the short run effect of an increase in elderly on inflation and 0.21 is the long run effect with an adjustment process of 0.22 per period. In other words, the total long run effect of 1 percentage point more elderly is 0.21 , but in $t+1$ this initially results in $0.21^{*} 0.22$ reduction in inflation, in $\mathrm{t}+2$, this results in $0.22^{*}\left[0.21-\left(0.21^{*} 0.22\right)\right]$, and so on.

The coefficient for the short run effect is not statistically significant which makes sense conceptually since one cannot expect inflation rates to directly and instantaneously respond to a change in the share of the elderly. Because 
the estimate of the long run coefficient 0.21 is a recalculation from several coefficients, we need to recalculate the standard error to assess whether this long run effect is statistically significant. To do so, we can use the Bewley transformation regression. We first obtain an estimate of $\Delta \mathrm{Y}_{\mathrm{t}}$ by estimating an equation of the form: $\Delta \mathrm{Y}_{\mathrm{t}}=\mathrm{a}+\mathrm{b} \mathrm{Y}_{\mathrm{t}-1}+\mathrm{bX}+\mathrm{t} \Delta \mathrm{X}_{\mathrm{t}}+\mathrm{e}_{\mathrm{t}}$ (shown in column 2); and then taking the predicted values $\Delta \hat{Y}_{t}$ to estimate $Y_{t}=a+d_{0} \Delta \hat{Y}_{t}+d_{1} X_{t}-d 2 \Delta X_{t}+$ $\mathrm{m}_{\mathrm{t}}$ (shown in column 3). This reveals the long run effect is significant with a $\mathrm{p}$-value inferior to $0.05 .{ }^{82}$ Rerunning the same analysis without country fixed effects is substantially the same but the magnitude of the long run effect is larger.

Table 7: Single Equation Error Correction Model

\begin{tabular}{|c|c|c|c|}
\hline \multirow{3}{*}{$\begin{array}{l}\text { Column } \\
\text { Dependent variable } \\
\text { Lagged inflation }\end{array}$} & \multirow{2}{*}{\multicolumn{2}{|c|}{$\begin{array}{l}(1) \\
\text { Inflation first difference }\end{array}$}} & \multirow{2}{*}{$\begin{array}{c}(3) \\
\text { Inflation rate } \\
\end{array}$} \\
\hline & & & \\
\hline & $-0.22^{* * *}$ & $-0.22^{* * *}$ & \\
\hline \multicolumn{4}{|l|}{ Elderly } \\
\hline First difference & 0.19 & 0.24 & 1.09 \\
\hline Lagged & -0.05 & & \\
\hline Level & & -0.05 & $-0.21 *$ \\
\hline \multicolumn{4}{|l|}{ GDP growth } \\
\hline First difference & $-0.37^{* * *}$ & $-0.35^{* * *}$ & $-1.59 * * *$ \\
\hline Lagged & -0.02 & & \\
\hline Level & & -0.02 & -0.08 \\
\hline \multicolumn{4}{|l|}{ Unemployment } \\
\hline First difference & $-0.34^{*}$ & -0.11 & $-0.51^{* *}$ \\
\hline Lagged & $-0.23^{* *}$ & & \\
\hline Level & & $-0.23^{* *}$ & $-1.03^{* * *}$ \\
\hline \multicolumn{4}{|l|}{ Trade openness } \\
\hline First difference & $0.15^{* *}$ & $0.13^{* *}$ & $0.61^{* * *}$ \\
\hline Lagged & 0.02 & & \\
\hline Level & & 0.02 & $0.08^{* * *}$ \\
\hline \multicolumn{4}{|c|}{ Central Bank Independence } \\
\hline First difference & -0.59 & 0.23 & 1.03 \\
\hline Lagged & -0.81 & & \\
\hline Level & & -0.81 & $-3.71^{* * *}$ \\
\hline \multicolumn{4}{|c|}{ Share of industrial employment } \\
\hline First difference & 5.93 & 0.19 & 0.85 \\
\hline Lagged & 5.74 & & \\
\hline Level & & 5.74 & $26.14^{* * *}$ \\
\hline Deficit & & & \\
\hline
\end{tabular}

${ }^{82}$ In using the Bewley (1979) transformation, we follow previous literature, see De Boef and Keele 2008. 
The impact of the elderly on inflation rates in developed countries

\begin{tabular}{|c|c|c|c|}
\hline \multirow{2}{*}{$\begin{array}{l}\text { Column } \\
\text { Dependent variable }\end{array}$} & (1) & (2) & \multirow{2}{*}{$\begin{array}{c}(3) \\
\text { Inflation rate }\end{array}$} \\
\hline & \multicolumn{2}{|c|}{ Inflation first difference } & \\
\hline First difference & 0.08 & $0.18^{* * *}$ & $0.82^{* * *}$ \\
\hline Lagged & $-0.10^{*}$ & & \\
\hline Level & & $-0.10^{*}$ & $-0.46^{* * *}$ \\
\hline Left share of cabinet & & & \\
\hline First difference & 0.00 & 0.00 & 0.01 \\
\hline Lagged & 0.00 & & \\
\hline Level & & 0.00 & $0.01^{* *}$ \\
\hline Union density & & & \\
\hline First difference & -0.02 & -0.05 & $-0.23^{* * *}$ \\
\hline Lagged & 0.03 & & \\
\hline Level & & 0.03 & $0.13^{* * *}$ \\
\hline Wage coordination & & & \\
\hline First difference & 0.02 & -0.07 & $-0.33^{* *}$ \\
\hline Lagged & 0.10 & & \\
\hline Level & & 0.10 & $0.44^{*}$ \\
\hline $\begin{array}{l}\text { Predicted change in inflation } \\
\text { rates (from column 2) }\end{array}$ & & & $-3.55^{* * *}$ \\
\hline Constant & -0.95 & -0.95 & $-4.34^{*}$ \\
\hline Observations & 678 & 678 & 678 \\
\hline R-squared & 0.36 & 0.36 & 0.81 \\
\hline Number of countries & 21 & 21 & 21 \\
\hline Country fixed effects & Yes & Yes & Yes \\
\hline Time effects & No & No & No \\
\hline R-squared within model & 0.36 & 0.36 & 0.81 \\
\hline R-squared overall model & 0.22 & 0.22 & 0.79 \\
\hline R-squared between model & 0.33 & 0.33 & 0.79 \\
\hline
\end{tabular}

\section{World sample}

We have now seen that the share of the elderly is robustly associated with inflation rates across OECD countries and I have provided some evidence for the existence of the causal mechanism that my argument implies. One problem with focusing on OECD countries is that the secular rise in the share of the old coincides with several structural changes in the economic structures of OECD economies. To address this issue, I collected data on a much larger sample including 216 countries $^{83}$ which also allows me to investigate whether

\footnotetext{
${ }^{83}$ Depending on specifications, there are between 216 and about 100 countries, because data availability is not the same for different variables.
} 
my argument 'travels' to developing and emerging economies. In table 8, I test my argument on this sample in the period between 1960 and 2013 (though this varies depending on the country and the full model only covers recent times). An issue with this larger sample is that some countries exhibit particularly high levels of inflation (sometimes above 100\%) which may bias the analysis. Table 8 shows results with different criteria for excluding outliers: column (1) imposes no restrictions, in column (2) I exclude observations where inflation is above $100 \%$, and in column (3) I do the same for a lower cut-off point of 50\%. Excluding observations 'wastes' information so I also try an alternative which consists of using a logarithmic transformation of the dependent variable: this compresses the values for outliers but does not exclude them ${ }^{84}$. Column (4) shows results with neither country nor time effects, column (5) includes time effects, and column (6) includes both time and country effects. In all specifications, the share of elderly is negatively associated with inflation.

A downside of having such a large coverage of countries is that data availability is not as good as for OECD countries. Nevertheless, columns (7) to (10) introduce - stepwise - additional variables ${ }^{85}$ that are available for some of my sample: GPD growth (column 7), unemployment rate (column 8), an index of democracy and the size of stock market (column 9), and left control of the executive (column 10). In column (11), I include country fixed effects to see whether this changes the results. In column 12, I include a measure of output gap which is not statistically significant. The results concerning the effect of elderly on inflation are robust throughout.

A final issue concerns ruling out alternative causal mechanisms through

\footnotetext{
${ }^{84} \mathrm{~A}$ downside is that this focuses only on positive values, since negative values become 0 after the logarithmic transformation.

85 The sources and description for the variables are available in table A2 in the appendix.
} 
The impact of the elderly on inflation rates in developed countries

which a larger share of elderly in the population could affect inflation rates. My argument is that the impact of the elderly operates through the electoral arena. However, if older people have different - less inflationary consumption and investment behaviours, I could observe a negative association that does not work through the electoral mechanism. I have already attempted to substantiate my causal mechanism by showing that the share of elderly affect both party manifestos and policies that influence inflation rates.

One way to rule out a non-electoral mechanism is to compare the effect of the elderly on inflation rates in countries with different degrees of democracy, which I measure using an additive index of the degree of democracy that takes values between 0 and 10 (where higher values suggest the country is more democratic). To give a sense of which countries the index identifies as fully democratic, I plot the change in the consumer price index against the share of the elderly in all countries that have a score of 10 in Figure 5. In column (13) of table 8, I interact the share of elderly with this index of democracy. The interaction effect cannot directly be interpreted from the table ${ }^{86}$. Figure 6 plots the marginal effect of the elderly on inflation conditional on democracy and shows that the share of elderly is only negatively and significantly associated when countries have a democratic score of 9 or 10 (i.e. when they have high democracy scores). If the causal mechanism operated mainly through a non-electoral arena, the effect would be statistically significant regardless of the degree of democracy.

${ }^{86}$ See Kam and Francese 2007. 
Figure 5: CPI and share of population above 65 in all countries with a democratic score of 10

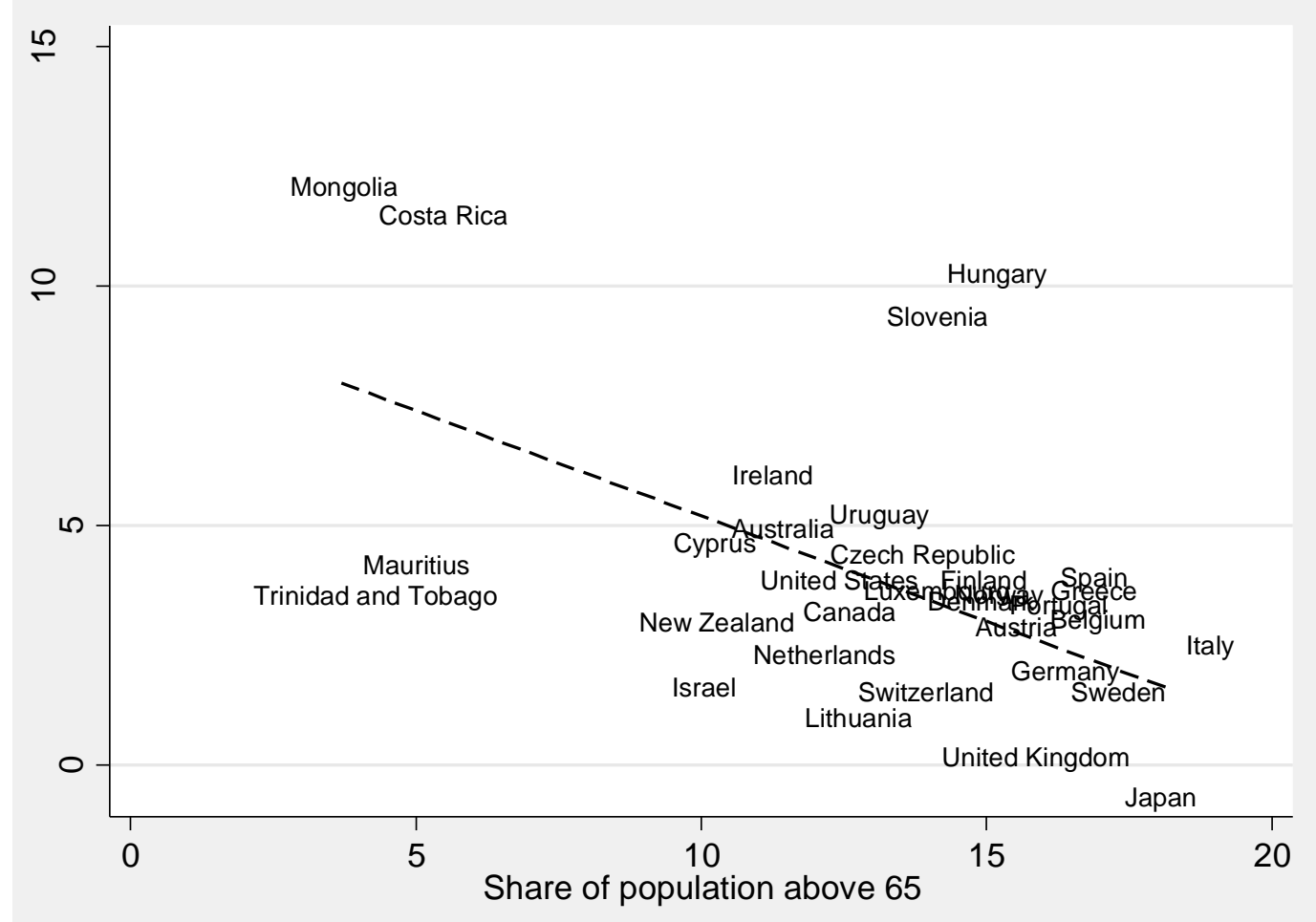

Note: democratic countries score of 10 using institutionalised democracy index, year 2000.

Table 8: Results for world sample

\begin{tabular}{|c|c|c|c|c|c|c|}
\hline $\begin{array}{l}\text { Column } \\
\text { Dependent } \\
\text { variable }\end{array}$ & $\begin{array}{l}(1) \\
C P I\end{array}$ & $\begin{array}{l}\text { (2) } \\
C P I\end{array}$ & $\begin{array}{l}\text { (3) } \\
\text { CPI }\end{array}$ & $\begin{array}{l}(4) \\
\operatorname{Ln}(C P I)\end{array}$ & $\begin{array}{l}\text { (5) } \\
\operatorname{Ln}(C P I)\end{array}$ & $\begin{array}{l}(6) \\
\operatorname{Ln}(C P I)\end{array}$ \\
\hline $\begin{array}{l}\text { Population }>65 \\
\text { (\% of total) }\end{array}$ & $\begin{array}{l}-6.78^{*} \\
(2.916)\end{array}$ & $\begin{array}{l}-1.15^{* * *} \\
(0.272) \\
\end{array}$ & $\begin{array}{l}-0.91^{* * *} \\
(0.169)\end{array}$ & $\begin{array}{l}-0.12^{* * *} \\
(0.013)\end{array}$ & $\begin{array}{l}-0.10^{* * *} \\
(0.015)\end{array}$ & $\begin{array}{l}-0.20^{* * *} \\
(0.028) \\
\end{array}$ \\
\hline Constant & $41.64^{* *}$ & $8.48^{* * *}$ & $7.41^{* * *}$ & $2.62^{* * *}$ & $1.51^{* * *}$ & $1.91^{* * *}$ \\
\hline Observations & 6,505 & 6,371 & 6,232 & 6,182 & 6,182 & 6,182 \\
\hline $\begin{array}{l}\text { Number of } \\
\text { countries }\end{array}$ & 175 & 175 & 175 & 175 & 175 & 175 \\
\hline $\begin{array}{l}\text { Country fixed } \\
\text { effects }\end{array}$ & Yes & Yes & Yes & No & No & Yes \\
\hline Time effects & Yes & Yes & Yes & No & Yes & Yes \\
\hline Period & $\begin{array}{l}1961- \\
2013\end{array}$ & $\begin{array}{l}1961- \\
2013\end{array}$ & $\begin{array}{l}1961- \\
2013\end{array}$ & $\begin{array}{l}1961- \\
2013\end{array}$ & $\begin{array}{l}1961- \\
2013\end{array}$ & $\begin{array}{l}1961- \\
2013\end{array}$ \\
\hline $\begin{array}{l}\text { Restrictions on } \\
\text { sample }\end{array}$ & None & $\mathrm{CPI}<100$ & $\mathrm{CPI}<50$ & Logarithm & $\begin{array}{l}\text { in } \\
\text { logarithm }\end{array}$ & $\begin{array}{l}\text { in } \\
\text { logarithm }\end{array}$ \\
\hline $\begin{array}{l}\text { R-squared overall } \\
\text { model }\end{array}$ & 0.01 & 0.08 & 0.13 & 0.03 & 0.15 & 0.11 \\
\hline
\end{tabular}

Note: robust standard errors clustered by country in parentheses; ${ }^{* * *} p<0.001,{ }^{* *} p<0.01,{ }^{*}$ $p<0.05$. 
The impact of the elderly on inflation rates in developed countries

Table 8 (continued): Results for world sample

\begin{tabular}{|c|c|c|c|c|c|c|c|}
\hline $\begin{array}{l}\text { Column } \\
\text { Dependent variable }\end{array}$ & $\begin{array}{l}\text { (7) } \\
\text { CPI }\end{array}$ & $\begin{array}{l}\text { (8) } \\
\text { CPI }\end{array}$ & $\begin{array}{l}(9) \\
\text { CPI }\end{array}$ & $\begin{array}{l}(10) \\
\text { CPI }\end{array}$ & $\begin{array}{l}(11) \\
\operatorname{Ln}(\mathrm{CPI})\end{array}$ & $\begin{array}{l}(12) \\
\text { CPI }\end{array}$ & $\begin{array}{l}\text { (13) } \\
\text { CPI }\end{array}$ \\
\hline Population $>65$ & $-1.11^{* * *}$ & $-0.35^{* * *}$ & $-0.30^{*}$ & $-0.30 *$ & $-0.19 * * *$ & $-0.183^{*}$ & 0.84 \\
\hline (\% of total) & $(0.277)$ & $(0.085)$ & $(0.137)$ & (0.137) & $(0.056)$ & $(0.0974)$ & $(0.490)$ \\
\hline GDP growth & $-0.12^{* *}$ & $\begin{array}{l}-0.12^{*} \\
(0.050)\end{array}$ & $\begin{array}{l}-0.30^{* * *} \\
(0.84)\end{array}$ & $\begin{array}{l}-0.31^{* * *} \\
(0.84)\end{array}$ & $\begin{array}{l}-0.03^{* *} \\
(0.009)\end{array}$ & $\begin{array}{l}-0.100^{* *} \\
(0.0455)\end{array}$ & $\begin{array}{l}-0.14^{*} \\
0.067)\end{array}$ \\
\hline $\begin{array}{l}\text { Unemployment } \\
\text { rate }\end{array}$ & $(0.044)$ & $\begin{array}{l}(0.050) \\
-0.02\end{array}$ & $\begin{array}{l}(0.084) \\
-0.11\end{array}$ & $\begin{array}{l}(0.084) \\
-0.11\end{array}$ & $\begin{array}{l}(0.009) \\
-0.04^{*}\end{array}$ & $\begin{array}{l}(0.0495) \\
-0.133\end{array}$ & $\begin{array}{l}(0.067) \\
0.01\end{array}$ \\
\hline (ILO definition) & & $(0.107)$ & $(0.119)$ & $(0.119)$ & $(0.018)$ & $(0.0890)$ & $(0.106)$ \\
\hline Democratic index & & & $\begin{array}{l}-0.32 \\
(0.240)\end{array}$ & $\begin{array}{l}-0.33 \\
(0.238)\end{array}$ & $\begin{array}{l}-0.03 \\
(0.023)\end{array}$ & $\begin{array}{l}-1.142^{* * *} \\
(0.429)\end{array}$ & $\begin{array}{l}0.24 \\
(0.314)\end{array}$ \\
\hline $\begin{array}{l}\text { Stock traded } \\
(\% \text { GDP) }\end{array}$ & & & $\begin{array}{l}0.01^{*} \\
(0.006)\end{array}$ & $\begin{array}{l}0.01^{*} \\
(0.006)\end{array}$ & $\begin{array}{l}0.00^{*} \\
(0.001)\end{array}$ & $\begin{array}{l}-0.00088 \\
(0.00163)\end{array}$ & \\
\hline $\begin{array}{l}\text { Left control } \\
\text { of executive }\end{array}$ & & & & $\begin{array}{l}0.15 \\
(0.606)\end{array}$ & $\begin{array}{l}-0.09 \\
(0.093)\end{array}$ & & \\
\hline Output gap & & & & & & $\begin{array}{l}0.0200 \\
(0.0636)\end{array}$ & \\
\hline Pop $>65^{*}$ Democracy & & & & & & & $\begin{array}{l}-0.12^{*} \\
(0.056)\end{array}$ \\
\hline Constant & $9.02^{* * *}$ & $18.44^{* * *}$ & $20.29 * * *$ & $20.29 * * *$ & $4.63^{* * *}$ & $20.73^{* * *}$ & $15.27^{* * *}$ \\
\hline Observations & 5,924 & 3,280 & 1,859 & 1,859 & 1,816 & 554 & 3,013 \\
\hline $\begin{array}{l}\text { Number of } \\
\text { countries }\end{array}$ & 175 & 163 & 105 & 105 & 105 & 26 & 154 \\
\hline $\begin{array}{l}\text { Country fixed } \\
\text { effects }\end{array}$ & Yes & No & No & No & Yes & No & No \\
\hline Time effects & No & Yes & Yes & Yes & Yes & Yes & Yes \\
\hline Period & $\begin{array}{l}1961- \\
2013\end{array}$ & $\begin{array}{l}1992- \\
2013\end{array}$ & $\begin{array}{l}1992- \\
2012\end{array}$ & $\begin{array}{l}1992- \\
2012\end{array}$ & $\begin{array}{l}1992- \\
2012\end{array}$ & $\begin{array}{l}1992- \\
2012\end{array}$ & $\begin{array}{l}1992- \\
2013\end{array}$ \\
\hline $\begin{array}{l}\text { Restrictions on } \\
\text { sample }\end{array}$ & $\begin{array}{l}\text { under } \\
100\end{array}$ & $\begin{array}{l}\text { under } \\
100\end{array}$ & $\begin{array}{l}\text { under } \\
100\end{array}$ & $\begin{array}{l}\text { under } \\
100\end{array}$ & logarithm & $\begin{array}{l}\text { Under } \\
100\end{array}$ & $\begin{array}{l}\text { under } \\
100\end{array}$ \\
\hline $\begin{array}{l}\text { R-squared overall } \\
\text { model }\end{array}$ & 0.08 & 0.10 & 0.09 & 0.09 & 0.09 & & 0.14 \\
\hline
\end{tabular}

Note: robust standard errors clustered by country in parentheses; ${ }^{* * *} p<0.001,{ }^{* *} p<0.01,{ }^{*}$ $p<0.05$. Results concerning the interaction effect from column (13) cannot be directly interpreted; instead refer to Figure 6. There is limited international data for output so the sample drops from 105 countries to 26 countries but still include countries that were not in tables 5 and 6 which only included 21 OECD countries: Estonia, Cyprus, Korea, Slovak Republic, and Slovenia. 
Figure 6: Effect of share of elderly on inflation depending on degree of democracy

Average Marginal Effects of population $>65$ with $95 \% \mathrm{Cls}$

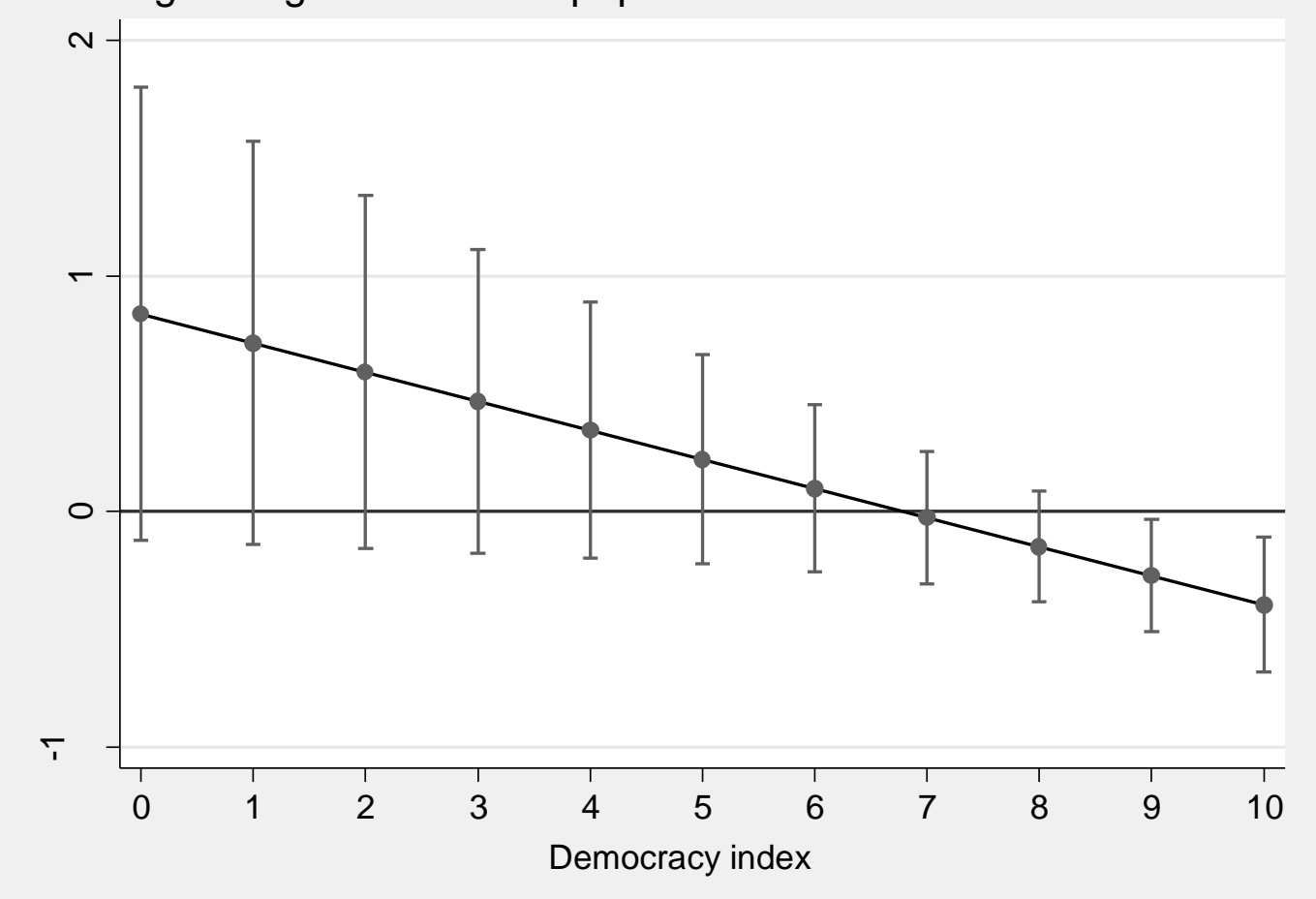

Note: results from column 12 in table 8.

\section{Conclusion}

The conventional wisdom in the comparative political economy literature analysing the determinants of inflation emphasises the role of ideas and institutions, and to a lesser extent interest group politics. While valuable, this paper has argued that by neglecting the role of domestic interests in the electoral arena, these explanations miss out an important determinant of cross-national variation in inflation rates and a potent explanation for the relative success of different ideas and institutions. For both methodological and theoretical reasons, this paper has focused on the share of elderly to show how electoral politics affects inflation rates. 
The impact of the elderly on inflation rates in developed countries

Specifically, I have argued that countries with a larger share of elderly should exhibit lower inflation because these voters are more inflation averse and sufficiently politically powerful to influence government preferences for inflation. My findings support my argument: older voters are more inflation averse, countries with more elderly have more economically orthodox political parties, higher central bank independence, and ultimately lower inflation. I have tested this latter association between the elderly and inflation rates using a wide variety of specifications, methods, and samples (including a very large sample including all countries in the world for which there is data). My results further show that the magnitude of this effect is sufficiently strong to suggest we were missing an important determinant of inflation rates.

Though this is a fairly circumscribed finding considering the effect of only one key factor - the share of elderly - on one main economic outcome inflation, this represents an important contribution to the comparative political economy literature in three ways.

First, this shows convincingly that domestic electoral politics, not just institutions, ideas, or interest groups, also matter for explaining inflation rates. Further research should analyse the impact of other electoral groups on inflation. For instance, it might be the case that electoral groups that are more insulated from the risk of unemployment, for instance because of higher employment protection legislation, and have housing assets, are more concerned about inflation than about unemployment. This may point to other sources of possible electoral support for low inflation in the electorate.

Second, this suggests ageing societies may have important effects on other economic outcomes and policies. The impact of ageing on other economic 
outcomes would represent a valuable avenue for further research. For instance, it might be that the elderly's comparatively lower concern for labour market performance make them indifferent to austerity policies that do not affect them directly; e.g. lower spending on labour market policies (as opposed to austerity that do affect them such as pension or health care cuts). This would explain the surprising electoral viability of certain austerity policies that would have been expected to lead to a greater electoral backlash.

Finally, as countries' populations continue to age, the political imperative to keep inflation low may supersede even pareto superior economic policies. Ageing may have represented a powerful driver behind the move to a low inflation regime in the past decades. As Western countries continue to age, this may lock us into a political equilibrium that is increasingly sub-optimal from an economic point of view. 
The impact of the elderly on inflation rates in developed countries

\section{References}

Alesina Alberto, Roubini Nouriel, and Cohen, Gerald D. 1997. Political Cycles and the Macroeconomy. Cambridge, Massachusetts: MIT Press.

Alesina, A., and Summers, L. 1993. "Central Bank Independence and Macroeconomic Performance: Some Comparative Evidence," Journal of Money, Credit and Banking 25, No. 2: 151-62.

Alesina, Alberto. 1989. "Politics and business cycles in industrial democracies," Economic Policy 4, No 8. (April): 57-98.

Bach, G. L. and Stephenson, James B. 1974. "Inflation and the redistribution of wealth". Review of Economics and Statistics 61 (February): 1-13.

Bade, Robin, and Parkin, Michael. 1978. "Central Bank Laws and Monetary Policy: A Preliminary Investigation". Dept. of Economics, University of Western Ontario

Bade, Robin, and Parkin, Michael. 1988. "Central Bank Laws and Monetary Policy". Department of Economics, University of Western Ontario, Canada.

Barro, Roberto J., Gordon, David B. 1983. "A positive theory of monetary policy in a natural rate model". The Journal of Political Economy 91, No 4 (August):589-610.

Barro, Robert and Gordon, David. 1983b. "Rules, Discretion and Reputation in a Model of Monetary Policy", Journal of Monetary Economics, 12, 101-21.

Berger, Helge, de Haan, Jacob, and Eijffinger, Sylvester. 2001. "Central Bank independence: an update of theory and evidence." Journal of Economic Surveys 15 Issue 1 (February): 3-40.

Bernhard, W. 1996. "Commitment, Continuity and Change: Political Parties and Central Bank Independence". Duke University, Raleigh, NC.

Bewley,R.A. 1979. "The Direct Estimation of the Equilibrium Response a Linea r Model." Economic Letters 3:357-361.

Boef, Suzanna De, and Keele, Luke. 2008."Taking Time Seriously." American Journal of Political Science 52 (1):184-200.

Bojar, Abel. 2015. "Biting the Hand that Feeds: Reconsidering Partisanship in an Age of Permanent Austerity”. LEQS Paper No. 91.

Busemeyer, Marius R. \& Schlicht-Schmälzle, Raphaela. 2014. "Partisan power, economic coordination and variations in vocational training systems in Europe". European Journal of Industrial Relations, 20(1): 1-17.

Calmfors, Lars, Driffill, John, Honkapohja, Seppo and Giavazzi, Francesco. 1988. "Bargaining structure, corporatism, and macroeconomic performance". Economic Policy 3 No. 6 (Apr.):14-61.

Cameron, David. 1984. "Social democracy, corporatism, labor quiescence, and the representation of economic interest in advanced capitalist society." In John H. Goldthorpe ed., Order and Conflict in Contemporary Capitalism. New York: Oxford University Press.

Campbell, Andrea Louse. 2003. "Participatory Reactions to Policy Threats: Senior Citizens and the Defense of Social Security and Medicare." Political Behavior 25 (March): 29-49.

Carlin, Wendy and Soskice David W. 2005.Macroeconomics:Imperfections, Institutions 
and Policies. Oxford, UK: Oxford University Press.

Chappell, Henry W. Jr., and Keech, William R. 1986. "Party Differences in Macroeconomic Policies and Outcomes." The American Economic Review 76, No. 2, (May): 71-74.

Clark, Williams Robert. 2003. Capitalism, Not Globalism: Capital Mobility, Central Bank Independence, and the Political Control of the Economy. Ann Arbor, MI: The University of Michigan Press.

Cukierman, Alex, Webb, Steven B. and Neyapti, Bilin. (1992). "Measuring the independence of central banks and its effect on policy outcomes". The World Bank Economic Review 6, No 3, (September):353-398.

Cukierman, Alex. 1992. Central Bank Strategy, Credibility, and Independence: Theory and Evidence. Cambridge, MA: The MIT Press.

Debelle, G. and S. Fischer. 1994. "How Independent Should a Central Bank Be?" In J.C. Fuhrer ed., Goals, Guidelines and Constraints Facing monetary Policymakers. Proceedings of a Conference Held at North Falmouth, Massachusetts. June 1994.

Eichengreen, Barry. 1997. "Institutions and economic growth: Europe after World War II". In Nicholas Crafts and Gianni Toniolo (eds.), Economic Growth in Europe Since 1945. Cambridge, UK: The University of Cambridge Press.

Eijffinger, Sylvester and de Haan, Jacob. 1996. The Political Economy of central-Bank Independence, Special Papers in International Economics, No. 19, Princeton University.

European Commission. 2014. "The 2015 Ageing Report Underlying Assumptions and Projection Methodologies". Manuscript. Brussels.

Fossati, Flavia \& Hausermann, Silja. 2014. "Social Policy Preferences and Party Choice in the2011 Swiss Elections."Swiss Political Science Review 20(4): 590-611.

Franzese, Robert J. 1999. "Partially independent central banks, politically responsive governments, and inflation." American Journal of Political Science 43, No 3 (July):681706.

Franzese, Robert J. 2002. Macroeconomic Policies of Developed Democracies. Cambridge, UK: Cambridge University Press.

Franzese, Robert J. 2003. "Multiple Hands on the Wheel: Empirically Modeling Partial Delegation and Shared Control of Monetary Policy in the Open and Institutionalized Economy." Political Analysis 11, No 4 (Autumn):445-74.

Friedman, Milton. 1968. "The role of monetary policy." American Economic Review 58, No 1 (March):1-17.

Giavazzi, Francesco and Marco Pagano. 1988. "The Advantage of Tying One's Hands: EMS Discipline and Central Bank Credibility", European Economic Review, 32, 105575.

Goerres, Achim. 2007. "Why are Older People More Likely toVote? The Impact of Ageing on Electoral Turnout in Europe."The British Journal of Politics and International Relations 9: 90-121.

Goerres, Achim. 2009. The Political Participation of Older People in Europe: The Greying of Our Democracies. Basingstoke, UK: Palgrave Macmillan.

Goodman, John B. 1991. "The Politics of Central Bank Independence," Comparative Politics 23, No 3 (April):329-349.

Grilli, Vittorio, Masciandaro D, Tabellini G. 1991. "Political and monetary institutions 
The impact of the elderly on inflation rates in developed countries

and public financial policies in the industrial countries." Economic Policy 13. Issue 6:341-92.

Hall PA, Franzese R. 1998. Mixed signals, central bank independence, coordinated wage bargaining and European monetary union. International Organisation 52, Issue 3:505-35.

Hancké, Bob. 2013. Unions, central banks and EMU: labour market institutions and monetary integration in Europe. Oxford, UK: Oxford University Press.

Häusermann, Silja. 2010. The Politics of Welfare State Reform in Continental Europe: Modernization in Hard Times. Cambridge: Cambridge University Press.

Hayo, Bernd. 1998. "Inflation culture, central bank independence and price stability." European Journal of Political Economy 14, Issue 2 (May): 241-263.

Hibbs, Douglas A. Jr. 1977. "Political Parties and Macroeconomic Policy," The American Political Science Review 71, No.4 (December): 1467-1487.

Hibbs, Douglas A. Jr. 1979. "The Mass Public and Macroeconomic Performance: The Dynamics of Public Opinion Toward Unemployment and Inflation." American Journal of Political Science 23, No. 4 (November): 705-731.

Hibbs, Douglas A. Jr. 1986. "Political parties and macroeconomic policies and outcomes in the United States." The American Economic Review 76, No.2 (May): 66-70.

Iversen Torben. 1998. "Wage bargaining, central bank independence and the real effects of money." International Organisation 52, No 3 (Summer):469-504.

Iversen, Torben. 1999. Contested Economic Institutions: The Politics of Macroeconomics and Wage Bargaining in Advanced Democracies. Cambridge, UK: Cambridge University Press.

Johnston, Alison. 2012. “European Economic and Monetary Union's perverse effects on sectoral wage inflation: Negative feedback effects from institutional change?" European Union Politics 13(3): 345-366.

Kaltenthaler, Karl C., and Anderson, Christopher J. 2000. "The Changing Political Economy of Inflation." Journal of Public Policy 20, Issue 2 (August): 109-131.

Kuttner, Kenneth and Posen, Adam. 2009. "Central Bank Independence: Conservative, yes, but causal?" Presentation at the ASSA Annual Meeting, San Francisco, January.

Kuttner, Kenneth K., and Posen, Adam S. 2001. "Beyond Bipolar: A Three Dimensional Assessment of Monetary Policy Frameworks," International Journal of Finance and Economics 6 Issue 4:369-387.

Laidler, David, ed. 1997. Where we go from here: inflation targets in Canada's Monetary Policy Regime. Toronto, CD: Howe Institute.

Lange P, Garrett G. 1985. "The politics of growth: strategic interaction and economic performance in the Advanced Industrial Democracies, 1974-1980." The Journal of Politics 47 Issue 3:792-82.

Lohmann, Susanne. 1992. "Optimal Commitment in Monetary Policy: Credibility versus Flexibility" The American Economic Review 82, No.1 (March): 273-286.

Lohmann, Susanne. 1998. "Federalism and Central Bank Independence: The Politics of German Monetary Policy, 1957-92,” World Politics 50, No. 3 (April): 401-46.

Lynch J. 2006. "Pension Inequality and Pension Policy Preferences in Europe: SelfInterest, Policy Feedbacks, or None of the Above?" Council for European Studies Working Paper, Columbia University. 
Lynch, Julia and Myrskylä, Mikko. 2009. "Always the third rail?: pension income and policy preferences in European democracies." Comparative Political Studies, 42 (8). pp. 1068-1097

MacRae, Duncan. 1977. "A political model of the business cycle." Journal of Political Economy 85, No.2 (April):239-63.

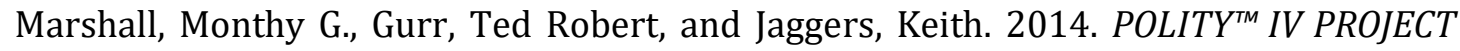
Political Regime Characteristics and Transitions, 1800-2013. At http://www.systemicpeace.org/inscrdata.html, accessed July, 18.15.

Marx, Paul \& Picot, Georg. 2014. "Labour market policies and party preferences of fixedterm workers." In Staffan Kumlin \&, Isabelle Stadelmann-Steffen, eds. How Welfare States Shape the Democratic Public: Policy Feedback, Participation, Voting, and Attitudes. Cheltanham \& Northampton, UK: Edward Elgar Publishing Ltd.

Maxfield, Sylvia. 1997. Gatekeepers of growth: the international political economy of central banking in developing countries. Princeton, NJ: Princeton University Press.

Miller, Geoffrey P. 1998. "An Interest-Group Theory of Central Bank Independence." The Journal of Legal Studies 27, No. 2 (June): 433-453.

Nordhaus, William D. 1975. "The political business cycle." The Review of Economic Studies 42, No. 2, (April):169-90.

Pierson, P. 1994. Dismantling the Welfare State? Reagan, Thatcher and the Politics of Retrenchment. Cambridge, UK: Cambridge University Press.

-__ 1998. "Irresistible Forces, Immovable Objects: Post-Industrial Welfare States Confront Permanent Austerity." Journal of European Public Policy 5 Issue 4: 539-60.

_-_1996. "The New Politics of the Welfare State." World politics 48 Issue 2: 143-179.

—_- ed. 2001.The New Politics of the Welfare State. Oxford, UK: Oxford University Press.

Posen, Adam S. 1995a. "Declarations Are Not Enough: Financial Sector Sources of Central Bank Independence" in Ben S. Bernanke and Julio J. Rotemberg, eds. NBER Macroeconomics Annual, Volume 10.

Posen, Adam S., 1993. "Why Central Bank Independence Does Not Cause Low Inflation: There is No Institutional Fix for Politics." in R. O'Brien (ed.), Finance and the International Economy. Oxford, UK: Oxford University Press.

Posen, Adam S.1995b. "Central bank independence and disinflationary credibility: A missing link?" Federal Reserve Bank of New York Staff Reports 1, May.

Rogoff, Kenneth. 1985. "The Optimal Commitment to an Intermediate Monetary Target." The Quarterly Journal of Economics 100 (November): 1169-1189.

Rueda, David. 2006. "Social Democracy and Active Labour-Market Policies: Insiders, Outsiders and the Politics of Employment Promotion." British Journal of Political Science 36, No. 3: 385-406.

Sakamoto, Takayuki. 2005. "Economic performance of 'weak' governments and their interaction with central banks and labour: Deficits, economic growth, unemployment and inflation, 1961-1998." European Journal of Political Research 44, Issue 6, (October): 801-836.

Scharpf, Fritz W. 1987. "A Game-Theoretical Interpretation of Inflation and Unemployment in Western Europe." Journal of Public Policy 7, Issue 3 (July): 227-57.

Scheve, Kenneth. 2004. "Public Inflation Aversion and the Political Economy of 
The impact of the elderly on inflation rates in developed countries

Macroeconomic Policymaking." International Organisation 58: No 1 (Winter): 1-34.

Schulz, James, H., and Binstock, Robert H. 2008. Aging Nation: The Economics and Politics of Growing Older in America. Baltimore, MD: John Hopkins University Press.

Sinn, H.W., and Uebelmesser, S. 2002. "Pensions and the Path to Gerontocracy in Germany." European Journal of Political Economy 19:153-158.

Tepe, Markus, and Vanhuysse, Pieter. 2009. "Are Aging Welfare States on the Path to the Politics of Gerontocracy? Evidence from 18 OECD Democracies, 1980-2002." Journal of Public Policy 29, No. 1 (January):1-28.

Visser. 2013. Data Base on Institutional Characteristics of Trade Unions, Wage Setting, State Intervention and Social Pacts, 1960-2011(ICTWSS). Amsterdam Institute for Advanced Labour Studies AIAS. University of Amsterdam. Version 4.April2013

Volkens, Andrea, Lehmann, Pola, Merz, Nicolas, Regel, Sven, Werner, Annika with Lacewell Onawa Promise, Schultze, Henrike. 2014: The Manifesto Data Collection. Manifesto Project (MRG / CMP / MARPOR). Version 2014b. Berlin: Wissenschaftszentrum Berlin fürSozialforschung (WZB).

Way, Christopher. 2000. "Central banks, partisan politics, and macroeconomic outcomes." Comparative Political Studies 33 No 2 (March): 196-224.

Woolley, John T. 1984. Monetary politics: the Federal Reserve and the politics of monetary policy. Cambridge, UK: Cambridge University Press. 


\section{Appendix}

Table A1: Descriptive statistics, description and sources for OECD sample

\begin{tabular}{|c|c|c|c|c|c|c|c|}
\hline Variables & $\mathbf{N}$ & Mean & Std Dev & $\min$ & $\max$ & Descriptions & Sources \\
\hline Inflation & 1,110 & 5.098 & 4.761 & -4.480 & 31.02 & $\begin{array}{l}\text { Growth of Consumer Price Index (all } \\
\text { items).Percentage change from } \\
\text { previous year. }\end{array}$ & Armingeon et al. $2014: 14$. \\
\hline Share of elderly & 1,113 & 13.249 & 3.024 & 5.727 & 24.15 & $\begin{array}{l}\text { Population over } 65 \text { as a percentage of } \\
\text { the whole population. }\end{array}$ & Armingeon et al. 2014:27. \\
\hline Real GDP growth & 1,092 & 3.048 & 2.796 & -8.539 & 13.20 & Percent change from previous year. & Armingeon et al. 2014:13. \\
\hline $\begin{array}{l}\text { Unemployment } \\
\text { rate }\end{array}$ & 1,113 & 5.743 & 4.044 & 0 & 25.13 & $\begin{array}{l}\text { Unemployment rate as a percentage of } \\
\text { the civilian labour force. }\end{array}$ & Armingeon et al. 2014:18. \\
\hline Openness & 1,091 & 60.075 & 30.789 & 9.354 & 187.8 & $\begin{array}{l}\text { Measured as total trade (sum of } \\
\text { import and export) } \\
\text { as a percentage of GDP, in current } \\
\text { prices. }\end{array}$ & Armingeon et al. 2014:12. \\
\hline Deficit & 992 & -.0754 & 3.529 & -28.03 & 16.10 & $\begin{array}{l}\text { Annual deficit excluding net interest } \\
\text { payments (government primary } \\
\text { balance), percentage of GDP. }\end{array}$ & Armingeon et al. 2014:15. \\
\hline Debt & 896 & 60.316 & 32.127 & 6.291 & 218.801 & $\begin{array}{l}\text { Gross government debt (financial } \\
\text { liabilities) as a percentage of GDP. }\end{array}$ & Armingeon et al. 2014: 10 \\
\hline $\begin{array}{l}\text { Central Bank } \\
\text { Independence }\end{array}$ & 849 & .408 & .189 & 0.0900 & 0.920 & $\begin{array}{l}\text { The Cukeirman-Webb-Neyapti Index } \\
\text { for Central Bank Independence }\end{array}$ & $\begin{array}{l}\text { Cukeirman et al. } 1992 . \\
\text { Updated using Simone } \\
\text { Polillo and Mauro F. } \\
\text { Guillén, “Globalization } \\
\text { Pressures and the State: } \\
\text { The Global Spread of } \\
\text { Central Bank } \\
\text { Independence.” American } \\
\text { Journal of Sociology } 110(6) \\
\text { (May 2005):1764-1802. }\end{array}$ \\
\hline Wage & 1,056 & 3.168 & 1.358 & 1 & 5 & Degrees of Coordination among & Visser 2013:9-10. \\
\hline
\end{tabular}




\begin{tabular}{|c|c|c|c|c|c|c|c|}
\hline Variables & $\mathbf{N}$ & Mean & Std Dev & $\min$ & $\max$ & Descriptions & Sources \\
\hline coordination & & & & & & different Institutions for Wage Setting. & \\
\hline Union density & 1,032 & 41.151 & 19.86 & 7.600 & 100 & $\begin{array}{l}\text { Net union membership as a } \\
\text { proportion of wage and salary earners } \\
\text { in employment. }\end{array}$ & Armingeon et al. 2014:20. \\
\hline Social transfer & 1,089 & 12.633 & 4.059 & 2.300 & 23.66 & $\begin{array}{l}\text { Social security transfers as a } \\
\text { percentage of GDP. }\end{array}$ & Armingeon et al. 2014:21. \\
\hline $\begin{array}{l}\text { Employment } \\
\text { protection } \\
\text { legislation for } \\
\text { regular workers } \\
\text { (OECD) }\end{array}$ & 583 & 2.12 & 0.92 & 9.26 & 5 & $\begin{array}{l}\text { Employment protection strictness } \\
\text { provided through legislation and as a } \\
\text { result of enforcement processes. Scale } \\
\text { of } 0-6 \text {; higher values indicate strict-er } \\
\text { employment protection }\end{array}$ & Armingeon et al. 2014:21. \\
\hline $\begin{array}{l}\text { Union } \\
\text { concentration }\end{array}$ & 923 & 0.311 & 0.114 & 0.113 & 0.587 & $\begin{array}{l}\text { Summary measure of concentration of } \\
\text { unions at peak and sectoral level }\end{array}$ & $\begin{array}{c}\text { ICTWSS - http://www.uva- } \\
\text { aias.net/ }\end{array}$ \\
\hline Capital openness & 871 & 1.440 & 1.267 & -1.875 & 2.421 & $\begin{array}{l}\text { Index for the degree of openness in } \\
\text { capital account transactions }\end{array}$ & $\begin{array}{l}\text { The Chinn- Ito Index. } \\
\text { Armingeon et al. } 2014\end{array}$ \\
\hline $\begin{array}{l}\text { Structural } \\
\text { unemployment }\end{array}$ & 1073 & 1.987 & 2.017 & 0 & 7 & Structural unemployment & OECD \\
\hline Home ownership & 678 & 54.966 & 12.922 & 28 & 78 & Housing owner occupation rate & $\begin{array}{l}\text { Data created by Andrew } \\
\text { Oswald }\end{array}$ \\
\hline $\begin{array}{l}\text { EPL (allard } \\
\text { index) }\end{array}$ & 814 & 1.622 & 1.101 & 0 & 4.1 & $\begin{array}{l}\text { This series uses the OECD } \\
\text { methodology generating an index }\end{array}$ & $\begin{array}{c}\text { Allard, G. (2005a), } \\
\text { "Measuring Job Security }\end{array}$ \\
\hline
\end{tabular}


Tim Vlandas

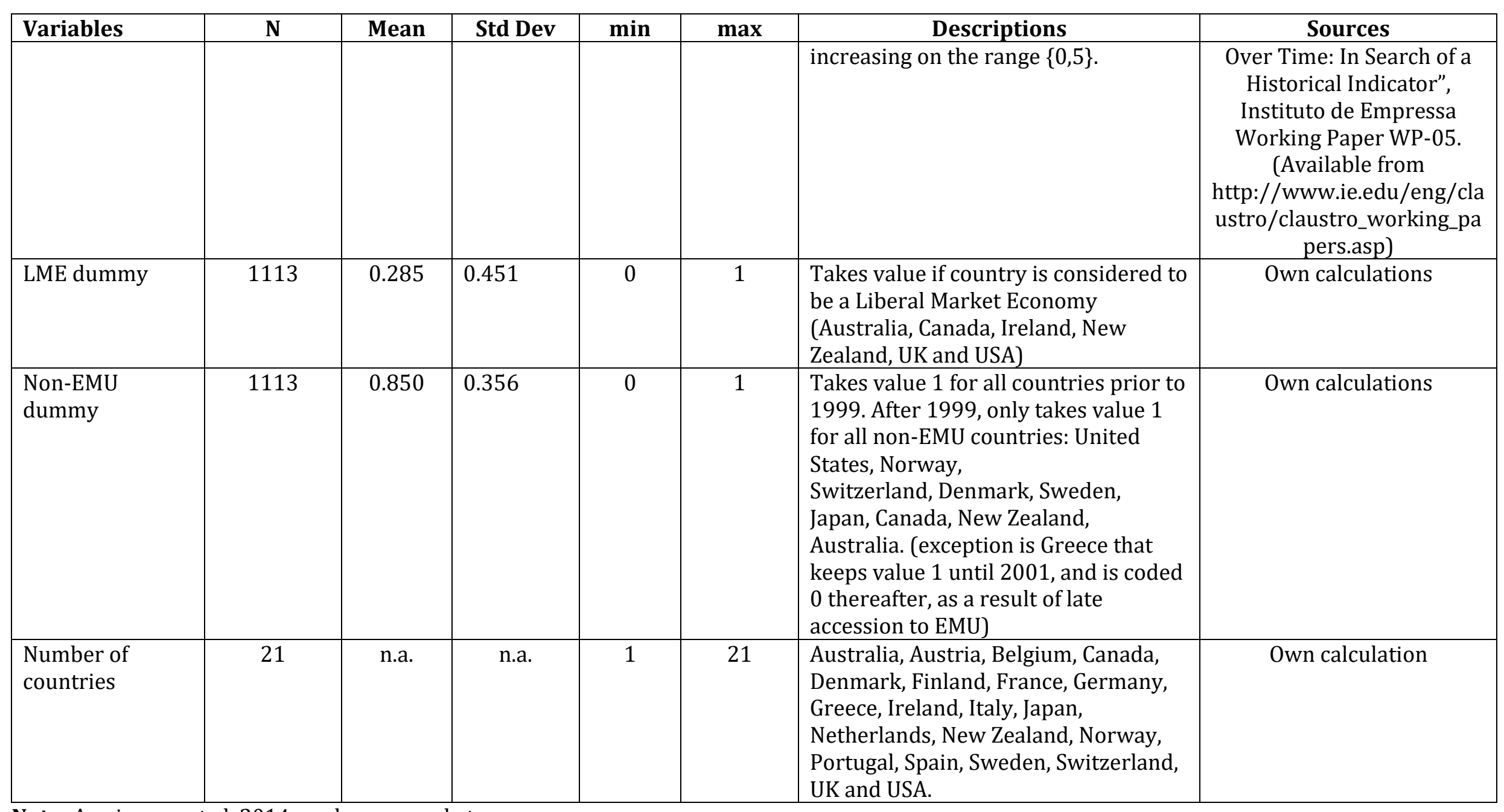

Note: Armingeon et al. 2014 can be accessed at:

http://www.ipw.unibe.ch/content/team/klaus armingeon/comparative political data sets/index eng.html 
The impact of the elderly on inflation rates in developed countries

\section{Table A2: Description and sources for world sample}

\begin{tabular}{|c|c|c|}
\hline Variables & Descriptions & Sources \\
\hline Inflation & $\begin{array}{l}\text { Inflation, consumer prices (annual \%). Inflation as measured by the } \\
\text { consumer price index reflects the annual percentage change in the cost } \\
\text { to the average consumer of acquiring a basket of goods and services } \\
\text { that may be fixed or changed at specified intervals, such as yearly. The } \\
\text { Laspeyres formula is generally used. }\end{array}$ & $\begin{array}{l}\text { International Monetary Fund, } \\
\text { International Financial Statistics and } \\
\text { data files. }\end{array}$ \\
\hline Elderly & $\begin{array}{l}\text { Population ages } 65 \text { and above as a percentage of the total population. } \\
\text { Population is based on the de facto definition of population, which } \\
\text { counts all residents regardless of legal status or citizenship--except for } \\
\text { refugees not permanently settled in the country of asylum, who are } \\
\text { generally considered part of the population of the country of origin. }\end{array}$ & $\begin{array}{l}\text { The United Nations Population } \\
\text { Division's World Population Prospects }\end{array}$ \\
\hline GDP growth & $\begin{array}{l}\text { Annual percentage growth rate of GDP at market prices based on } \\
\text { constant local currency. Aggregates are based on constant } 2005 \text { U.S. } \\
\text { dollars. GDP is the sum of gross value added by all resident producers } \\
\text { in the economy plus any product taxes and minus any subsidies not } \\
\text { included in the value of the products. It is calculated without making } \\
\text { deductions for depreciation of fabricated assets or for depletion and } \\
\text { degradation of natural resources. }\end{array}$ & $\begin{array}{l}\text { World Bank national accounts data, } \\
\text { and OECD National Accounts data files. }\end{array}$ \\
\hline Unemployment rate & $\begin{array}{l}\text { Unemployment refers to the share of the labor force that is without } \\
\text { work but available for and seeking employment. }\end{array}$ & $\begin{array}{l}\text { International Labour Organization, Key } \\
\text { Indicators of the Labour Market } \\
\text { database. }\end{array}$ \\
\hline Democratic index & $\begin{array}{l}\text { Institutionalised Democracy index. Democracy is conceived as three } \\
\text { essential, interdependent elements. One is the presence of institutions } \\
\text { and procedures through which citizens can express effective } \\
\text { preferences about alternative policies and leaders. Second is the } \\
\text { existence of institutionalized constraints on the exercise of power by } \\
\text { the executive. Third is the guarantee of civil liberties to all citizens in } \\
\text { their daily lives and in acts of political participation. Other aspects of } \\
\text { plural democracy, such as the rule of law, systems of checks and } \\
\text { balances, freedom of the press, and so on are means to, or specific } \\
\text { manifestations of, these general principles. The Democracy indicator is } \\
\text { an additive eleven-point scale }(0-10) \text {. }\end{array}$ & \\
\hline
\end{tabular}


Tim Vlandas

\begin{tabular}{|l|l|l|}
\hline Variables & \multicolumn{1}{|c|}{ Descriptions } & \multicolumn{1}{|c|}{ Sources } \\
\hline Stock traded & $\begin{array}{l}\text { Stocks traded refers to the total value of shares traded during the } \\
\text { period. This indicator complements the market capitalization ratio by } \\
\text { showing whether market size is matched by trading. }\end{array}$ & $\begin{array}{l}\text { Standard \& Poor's, Global Stock } \\
\text { Markets Factbook and supplemental } \\
\text { S\&P data. }\end{array}$ \\
\hline Left control & $\begin{array}{l}\text { Executive control by Right (1); Left (3); Center (2); No executive (NA). } \\
\text { Recoded as a dichotomous variable taking value 1 if control by left and } \\
\text { 0 otherwise. See page Beck et al. (2001):7-9. }\end{array}$ & $\begin{array}{l}\text { Thorsten Beck, George Clarke, Alberto } \\
\text { Groff, Philip Keefer, and Patrick Walsh, } \\
2001 . \text { "New tools in comparative } \\
\text { political economy: The Database of } \\
\text { Political Institutions." 15:1, 165-176 } \\
\text { (September), World Bank Economic } \\
\text { Review. }\end{array}$ \\
\hline Output gap & $\begin{array}{l}\text { Output gap in percent of potential GDP (Percent of potential GDP). } \\
\text { Output gaps for advanced economies are calculated as actual GDP less } \\
\text { potential GDP as a percent of potential GDP. Estimates of output gaps } \\
\text { are subject to a significant margin of uncertainty. For a discussion of } \\
\text { approaches to calculating potential output, see Paula R. De Masi, IMF } \\
\text { Estimates of Potential Output: Theory and Practice, in Staff Studies for } \\
\text { the World Economic Outlook (Washington: IMF, December 1997), pp. } \\
\text { 40-46. }\end{array}$ & $\begin{array}{l}\text { International Monetary Fund, World } \\
\text { https://www.imf.org/external/pubs/ft } \\
\text { /weo/2015/01/weodata/index.aspx }\end{array}$ \\
\hline
\end{tabular}


The impact of the elderly on inflation rates in developed countries

Table A3: Testing the effect of additional factors

\begin{tabular}{|c|c|c|c|c|c|c|}
\hline Column & (1) & $(2)$ & (3) & (4) & (5) & (6) \\
\hline Inflation & $0.86^{* * *}$ & & & & & \\
\hline (lagged once) & $(0.024)$ & & & & & \\
\hline Elderly & $-0.10^{*}$ & $-0.77^{* * *}$ & $-0.74^{* *}$ & $-0.99 * * *$ & $-0.98^{* * *}$ & $-0.81^{* * *}$ \\
\hline (lagged in columns $2 \& 3$ ) & $(0.044)$ & $(0.227)$ & $(0.241)$ & $(0.144)$ & $(0.203)$ & $(0.216)$ \\
\hline \multirow[t]{2}{*}{ Real GDP growth } & -0.06 & $-0.57^{* * *}$ & $-0.55^{* * *}$ & $-0.61^{* * *}$ & $-0.65^{* * *}$ & $-0.67^{* * *}$ \\
\hline & $(0.057)$ & $(0.070)$ & $(0.064)$ & $(0.066)$ & $(0.059)$ & $(0.069)$ \\
\hline Unemployment rate & $-0.11^{* *}$ & $-0.56^{* * *}$ & $-0.67^{* * *}$ & $-0.42^{* * *}$ & $-0.58^{* * *}$ & $-0.49 * * *$ \\
\hline (lagged in columns $2 \& 3$ ) & $(0.036)$ & $(0.110)$ & $(0.103)$ & $(0.091)$ & $(0.073)$ & $(0.093)$ \\
\hline Deficit & 0.01 & $-0.34 * * *$ & $-0.33^{* *}$ & -0.19 & -0.19 & $-0.29 * *$ \\
\hline (lagged in columns $2 \& 3$ ) & $(0.038)$ & $(0.097)$ & $(0.094)$ & $(0.103)$ & $(0.099)$ & $(0.107)$ \\
\hline Trade openness & 0.01 & $0.08^{* * *}$ & $0.11^{* * *}$ & $0.03^{* *}$ & $0.08^{* *}$ & $0.07 * * *$ \\
\hline (lagged in columns $2 \& 3$ ) & $(0.004)$ & $(0.015)$ & $(0.022)$ & $(0.009)$ & $(0.020)$ & $(0.013)$ \\
\hline Left control of cabinet & 0.00 & 0.01 & 0.01 & 0.00 & 0.00 & $0.01^{*}$ \\
\hline (lagged in columns $2 \& 3$ ) & $(0.002)$ & $(0.006)$ & $(0.006)$ & $(0.004)$ & $(0.003)$ & $(0.004)$ \\
\hline Union density & -0.00 & $0.15^{* * *}$ & $0.19 * * *$ & $0.09 * * *$ & $0.19 * * *$ & $0.15^{* * *}$ \\
\hline (lagged in columns $2 \& 3$ ) & $(0.005)$ & $(0.044)$ & $(0.048)$ & $(0.027)$ & $(0.039)$ & $(0.041)$ \\
\hline \multirow[t]{2}{*}{ Central bank independence } & -0.15 & -2.53 & $-3.03^{*}$ & 1.86 & 0.33 & $-3.45^{* *}$ \\
\hline & $(0.479)$ & $(1.342)$ & $(1.440)$ & $(1.378)$ & $(1.501)$ & $(1.317)$ \\
\hline \multirow[t]{2}{*}{ Capital openness } & & & & $-1.60^{* * *}$ & $-1.18^{* *}$ & \\
\hline & & & & $(0.341)$ & $(0.351)$ & \\
\hline \multirow[t]{2}{*}{ Structural unemployment } & & & & & & 0.21 \\
\hline & & & & & & $(0.369)$ \\
\hline Constant & $2.64^{* * *}$ & $11.19^{* * *}$ & $7.62^{*}$ & $19.71^{* * *}$ & $13.87^{* * *}$ & $12.19 * * *$ \\
\hline Observations & 698 & 688 & 688 & 580 & 580 & 699 \\
\hline Number of countries & 21 & 21 & 21 & 21 & 21 & 21 \\
\hline Country fixed effects & No & No & Yes & No & Yes & No \\
\hline Time effects & No & No & No & No & No & No \\
\hline R-squared within model & 0.75 & 0.51 & 0.51 & 0.65 & 0.68 & 0.51 \\
\hline R-squared overall model & 0.80 & 0.10 & 0.07 & 0.42 & 0.20 & 0.09 \\
\hline R-squared between model & 0.98 & 0.03 & 0.03 & 0.09 & 0.00 & 0.07 \\
\hline
\end{tabular}

Note: Robust standard errors clustered by country in parentheses; ${ }^{* * *} p<0.001,{ }^{* *} p<0.01,{ }^{*} p<0.05$. 
Table A3 (continued): Testing the effect of additional factors

\begin{tabular}{|c|c|c|c|c|c|c|c|}
\hline Column & (7) & $(8)$ & (9) & $(10)$ & (11) & (12) & (13) \\
\hline Elderly & $-0.80^{* *}$ & $-0.43^{*}$ & $-0.71^{* *}$ & $-0.72^{* *}$ & $-0.74^{*}$ & $-1.06^{* * *}$ & $-0.91 * * *$ \\
\hline (lagged in columns $3 \& 4$ ) & $(0.234)$ & $(0.176)$ & $(0.192)$ & $(0.261)$ & $(0.268)$ & $(0.224)$ & $(0.218)$ \\
\hline Real GDP growth & $\begin{array}{c}-0.71^{* * *} \\
(0.060)\end{array}$ & $\begin{array}{c}-0.54^{* * *} \\
(0.077)\end{array}$ & $\begin{array}{c}-0.59^{* * *} \\
(0.060)\end{array}$ & $\begin{array}{c}-0.68^{* * *} \\
(0.063)\end{array}$ & $\begin{array}{c}-0.70^{* * *} \\
(0.059)\end{array}$ & $\begin{array}{c}-0.61^{* * *} \\
(0.072)\end{array}$ & $\begin{array}{c}-0.66^{* * *} \\
(0.064)\end{array}$ \\
\hline Unemployment rate & $-0.63^{* * *}$ & $-0.49 * * *$ & $-0.92^{* * *}$ & $-0.46^{* * *}$ & $-0.59 * * *$ & $-0.45^{* * *}$ & $-0.63^{* * *}$ \\
\hline (lagged in columns $3 \& 4$ ) & $(0.084)$ & $(0.109)$ & $(0.106)$ & $(0.076)$ & $(0.059)$ & $(0.093)$ & $(0.083)$ \\
\hline Deficit & $-0.26^{*}$ & $-0.35^{*}$ & $-0.30^{*}$ & $-0.28^{* *}$ & $-0.26^{*}$ & $-0.24^{*}$ & $-0.23^{*}$ \\
\hline (lagged in columns $3 \& 4$ ) & $(0.108)$ & $(0.147)$ & $(0.128)$ & $(0.106)$ & $(0.103)$ & $(0.111)$ & $(0.106)$ \\
\hline Trade openness & $0.12^{* * *}$ & 0.03 & $0.19 * * *$ & $0.09 * * *$ & $0.12^{* * *}$ & 0.03 & $0.09^{* *}$ \\
\hline (lagged in columns $3 \& 4$ ) & $(0.024)$ & $(0.018)$ & $(0.043)$ & $(0.017)$ & $(0.026)$ & $(0.014)$ & $(0.027)$ \\
\hline Left control of cabinet & $0.01^{* *}$ & $0.02 *$ & $0.02 *$ & $0.01 *$ & $0.01^{*}$ & 0.01 & $0.01^{* *}$ \\
\hline (lagged in columns $3 \& 4$ ) & $(0.004)$ & $(0.006)$ & $(0.006)$ & $(0.005)$ & $(0.004)$ & $(0.005)$ & $(0.004)$ \\
\hline Union density & $0.22^{* * *}$ & $0.06^{*}$ & $0.19^{* *}$ & $0.16^{* * *}$ & $0.21^{* * *}$ & $0.13^{* *}$ & $0.20^{* * *}$ \\
\hline (lagged in columns $3 \& 4$ ) & $(0.047)$ & $(0.029)$ & $(0.049)$ & $(0.045)$ & $(0.050)$ & $(0.039)$ & $(0.048)$ \\
\hline Central bank independence & $\begin{array}{l}-4.23^{* *} \\
(1.319)\end{array}$ & $\begin{array}{c}-3.65 \\
(2.721)\end{array}$ & $\begin{array}{c}-0.90 \\
(1.777)\end{array}$ & $\begin{array}{l}-3.57^{* *} \\
(1.217)\end{array}$ & $\begin{array}{l}-4.33^{* *} \\
(1.357)\end{array}$ & $\begin{array}{c}-1.68 \\
(1.609)\end{array}$ & $\begin{array}{c}-3.14 \\
(1.522)\end{array}$ \\
\hline Structural unemployment & $\begin{array}{c}-0.08 \\
(0.550)\end{array}$ & & & & & & \\
\hline Home ownership & & $\begin{array}{c}0.12^{* *} \\
(0.045)\end{array}$ & $\begin{array}{c}0.13 \\
(0.097)\end{array}$ & & & & \\
\hline Industry & & & & $\begin{array}{c}9.97 \\
(8.183)\end{array}$ & $\begin{array}{c}5.98 \\
(8.726)\end{array}$ & & \\
\hline $\begin{array}{l}\text { EPL } \\
\text { (Allard index) }\end{array}$ & & & & & & $\begin{array}{l}1.65^{* * *} \\
(0.432)\end{array}$ & $\begin{array}{c}0.97 \\
(0.498)\end{array}$ \\
\hline Constant & 8.45 & $19.17^{* * *}$ & $14.43^{*}$ & 7.24 & 5.53 & $16.30^{* * *}$ & $10.40^{* * *}$ \\
\hline Observations & 699 & 535 & 535 & 699 & 699 & 573 & 573 \\
\hline Number of countries & 21 & 19 & 19 & 21 & 21 & 20 & 20 \\
\hline Country fixed effects & Yes & No & Yes & No & Yes & No & Yes \\
\hline Time effects & No & No & No & No & No & No & No \\
\hline R-squared within model & 0.53 & 0.48 & 0.54 & 0.52 & 0.53 & 0.56 & 0.58 \\
\hline R-squared overall model & 0.06 & 0.23 & 0.09 & 0.09 & 0.06 & 0.16 & 0.09 \\
\hline R-squared between model & 0.03 & 0.02 & 0.03 & 0.04 & 0.04 & 0.04 & 0.03 \\
\hline
\end{tabular}

Note: Robust standard errors clustered by country in parentheses; ${ }^{* * *} p<0.001,{ }^{* *} p<0.01,{ }^{*} p<0.0$ 
The impact of the elderly on inflation rates in developed countries

Table A4: Excluding inflationary periods from analysis of determinants of inflation

\begin{tabular}{|c|c|c|c|}
\hline $\begin{array}{l}\text { Column } \\
\text { Dependent variable }\end{array}$ & (1) & $\begin{array}{c}(2) \\
\text { Inflation rate }\end{array}$ & (3) \\
\hline Share of elderly & $\begin{array}{l}-3.49^{* *} \\
(1.266)\end{array}$ & $\begin{array}{l}-3.27^{*} \\
(1.472)\end{array}$ & $\begin{array}{l}-2.07^{* *} \\
(0.704)\end{array}$ \\
\hline GDP growth & $\begin{array}{l}-1.64^{* * *} \\
(0.305)\end{array}$ & $\begin{array}{c}-1.62^{* * *} \\
(0.325)\end{array}$ & $\begin{array}{l}-0.70^{* * * *} \\
(0.150)\end{array}$ \\
\hline Unemployment rate & $\begin{array}{l}-1.83^{* *} \\
(0.580)\end{array}$ & $\begin{array}{c}-2.25^{* * *} \\
(0.550)\end{array}$ & $\begin{array}{l}-1.12^{*} \\
(0.511)\end{array}$ \\
\hline Deficit & $\begin{array}{c}-0.70^{*} \\
(0.285)\end{array}$ & $\begin{array}{l}-0.71 * \\
(0.285)\end{array}$ & $\begin{array}{c}0.11 \\
(0.137)\end{array}$ \\
\hline Trade openness & $\begin{array}{c}1.22 \\
(0.806)\end{array}$ & $\begin{array}{c}1.68 \\
(1.200)\end{array}$ & $\begin{array}{c}0.27 \\
(0.344)\end{array}$ \\
\hline Share of industrial employment & $\begin{array}{c}2.57^{* *} \\
(0.830)\end{array}$ & $\begin{array}{c}2.02 \\
(1.020)\end{array}$ & $\begin{array}{l}2.81^{* * *} \\
(0.563)\end{array}$ \\
\hline Left share of cabinet seats & $\begin{array}{c}0.03 \\
(0.167)\end{array}$ & $\begin{array}{c}-0.08 \\
(0.175)\end{array}$ & $\begin{array}{c}-0.37 \\
(0.215)\end{array}$ \\
\hline Union density & $\begin{array}{c}2.96^{*} \\
(1.153)\end{array}$ & $\begin{array}{l}4.31^{* *} \\
(1.496)\end{array}$ & $\begin{array}{c}0.87 \\
(0.541)\end{array}$ \\
\hline Social security transfers & $\begin{array}{c}-1.02 \\
(0.576)\end{array}$ & $\begin{array}{c}-0.91 \\
(0.662)\end{array}$ & $\begin{array}{c}0.47 \\
(0.370)\end{array}$ \\
\hline Central Bank Independence & $\begin{array}{c}0.06 \\
(0.249)\end{array}$ & $\begin{array}{c}-0.06 \\
(0.288)\end{array}$ & $\begin{array}{c}-0.13 \\
(0.174)\end{array}$ \\
\hline Wage coordination & $\begin{array}{l}-1.12^{* *} \\
(0.425)\end{array}$ & $\begin{array}{c}-0.97^{*} \\
(0.389)\end{array}$ & $\begin{array}{l}-1.00^{* *} \\
(0.384)\end{array}$ \\
\hline Constant & $\begin{array}{l}7.35^{* * *} \\
(1.090)\end{array}$ & $\begin{array}{l}7.51^{* * *} \\
(0.289)\end{array}$ & $\begin{array}{l}5.60^{* * *} \\
(1.161)\end{array}$ \\
\hline Observations & 406 & 406 & 210 \\
\hline Period & Post-1980 & Post-1980 & Post-1990 \\
\hline Number of countries & 21 & 21 & 21 \\
\hline Country fixed effects & No & Yes & No \\
\hline Time effects & No & No & No \\
\hline R-squared within model & 0.70 & 0.70 & 0.58 \\
\hline R-squared overall model & 0.19 & 0.11 & 0.03 \\
\hline R-squared between model & 0.01 & 0.02 & 0.10 \\
\hline
\end{tabular}

Note: Robust standard errors in parentheses; ${ }^{* * *} p<0.001,{ }^{* *} p<0.01,{ }^{*} p<0.05$. All

independent variables are standardised with mean 0 and standard deviation 1. 
Table A5: Determinants of central bank independence

\begin{tabular}{|c|c|c|c|c|}
\hline Column & $(1)$ & $(2)$ & (3) & $(4)$ \\
\hline Dependent variable & Central b & rindepen & nce index & $\begin{array}{c}\text { Increase in CBI } \\
\text { (binary) }\end{array}$ \\
\hline Share of elderly & $\begin{array}{l}0.13^{* * *} \\
(0.036)\end{array}$ & $\begin{array}{c}0.13^{* *} \\
(0.036)\end{array}$ & $\begin{array}{c}0.14^{* *} \\
(0.044)\end{array}$ & $\begin{array}{l}1.01^{*} \\
(0.430)\end{array}$ \\
\hline GDP growth & $\begin{array}{c}0.01 \\
(0.005)\end{array}$ & $\begin{array}{c}0.01 \\
(0.005)\end{array}$ & $\begin{array}{c}-0.01 \\
(0.006)\end{array}$ & $\begin{array}{c}-0.43 \\
(0.376)\end{array}$ \\
\hline Unemployment rate & $\begin{array}{c}0.03 \\
(0.018)\end{array}$ & $\begin{array}{c}0.03 \\
(0.019)\end{array}$ & $\begin{array}{c}0.05^{*} \\
(0.019)\end{array}$ & $\begin{array}{c}0.29^{*} \\
(0.120)\end{array}$ \\
\hline Deficit & $\begin{array}{c}0.02 \\
(0.014)\end{array}$ & $\begin{array}{c}0.02 \\
(0.014)\end{array}$ & $\begin{array}{c}0.02 \\
(0.015)\end{array}$ & $\begin{array}{c}0.36^{*} \\
(0.169)\end{array}$ \\
\hline Trade openness & $\begin{array}{c}0.06^{*} \\
(0.028)\end{array}$ & $\begin{array}{c}0.07^{*} \\
(0.031)\end{array}$ & $\begin{array}{c}0.07 \\
(0.037)\end{array}$ & $\begin{array}{c}0.36 \\
(0.233)\end{array}$ \\
\hline Share of industrial employment & $\begin{array}{c}0.00 \\
(0.030)\end{array}$ & $\begin{array}{c}0.00 \\
(0.031)\end{array}$ & $\begin{array}{c}-0.01 \\
(0.032)\end{array}$ & $\begin{array}{c}-0.08 \\
(0.320)\end{array}$ \\
\hline Left share of cabinet seats & $\begin{array}{c}-0.00 \\
(0.008)\end{array}$ & $\begin{array}{c}-0.00 \\
(0.008)\end{array}$ & $\begin{array}{c}-0.00 \\
(0.005)\end{array}$ & $\begin{array}{c}0.27 \\
(0.158)\end{array}$ \\
\hline Union density & $\begin{array}{c}-0.01 \\
(0.019)\end{array}$ & $\begin{array}{c}-0.00 \\
(0.021)\end{array}$ & $\begin{array}{c}0.01 \\
(0.022)\end{array}$ & $\begin{array}{l}-0.72^{* *} \\
(0.254)\end{array}$ \\
\hline Social security transfers & $\begin{array}{l}-0.08^{* *} \\
(0.027)\end{array}$ & $\begin{array}{l}-0.08^{* *} \\
(0.028)\end{array}$ & $\begin{array}{c}-0.05 \\
(0.023)\end{array}$ & $\begin{array}{c}-0.15 \\
(0.338)\end{array}$ \\
\hline Wage coordination & $\begin{array}{c}0.01 \\
(0.013)\end{array}$ & $\begin{array}{c}0.01 \\
(0.014)\end{array}$ & $\begin{array}{c}0.02 \\
(0.013)\end{array}$ & $\begin{array}{c}0.42 \\
(0.269)\end{array}$ \\
\hline Constant & $0.43^{* * *}$ & $0.43^{* * *}$ & $0.56^{* * *}$ & $-4.03^{* * *}$ \\
\hline Observations & 699 & 699 & 699 & 699 \\
\hline Number of countries & 21 & 21 & 21 & 21 \\
\hline Country fixed effects & No & Yes & Yes & No \\
\hline Time effects & No & No & Yes & No \\
\hline R-squared within model & 0.37 & 0.37 & 0.58 & \\
\hline R-squared overall model & 0.08 & 0.06 & 0.11 & \\
\hline R-squared between model & 0.01 & 0.00 & 0.00 & \\
\hline Pseudo R-squared & & & & 0.16 \\
\hline
\end{tabular}

Note: Robust standard errors in parentheses; ${ }^{* * *} p<0.001,{ }^{* *} p<0.01,{ }^{*} p<0.05$. All independent variables are standardised with mean 0 and standard deviation 1. 
The impact of the elderly on inflation rates in developed countries

Table A6: Linking elderly to economic orthodoxy, central bank independence and inflation rates

\begin{tabular}{|c|c|c|c|}
\hline $\begin{array}{l}\text { Column } \\
\text { Dependent variable }\end{array}$ & $\begin{array}{c}1) \\
\text { Economic } \\
\text { orthodoxy }\end{array}$ & $\begin{array}{c}\text { (2) } \\
\text { Central Bank } \\
\text { independence }\end{array}$ & $\begin{array}{c}3) \\
\text { Inflation rate }\end{array}$ \\
\hline Share of elderly & $\begin{array}{l}0.19^{* * *} \\
(0.065)\end{array}$ & $\begin{array}{c}0.04^{* *} \\
(0.017)\end{array}$ & $\begin{array}{l}-0.33^{* *} \\
(0.167)\end{array}$ \\
\hline Inflation rate & $\begin{array}{c}-0.08 \\
(0.082)\end{array}$ & & \\
\hline $\begin{array}{l}\text { Inflation rate } \\
\text { (lagged once) }\end{array}$ & & $\begin{array}{c}-0.00 \\
(0.008)\end{array}$ & \\
\hline Unemployment rate & $\begin{array}{c}-0.02 \\
(0.067)\end{array}$ & & $\begin{array}{c}-0.05 \\
(0.103)\end{array}$ \\
\hline $\begin{array}{l}\text { Unemployment rate } \\
\text { (lagged once) }\end{array}$ & & $\begin{array}{c}0.01 \\
(0.011)\end{array}$ & \\
\hline Deficit & $\begin{array}{c}0.04 \\
(0.078)\end{array}$ & $\begin{array}{c}0.00 \\
(0.012)\end{array}$ & $\begin{array}{c}-0.13 \\
(0.091)\end{array}$ \\
\hline Trade openness & $\begin{array}{c}0.01 \\
(0.011)\end{array}$ & $\begin{array}{c}0.00^{* *} \\
(0.002)\end{array}$ & $\begin{array}{l}-0.00 \\
(0.011)\end{array}$ \\
\hline Left share of cabinet seats & $\begin{array}{c}0.01^{*} \\
(0.005)\end{array}$ & $\begin{array}{c}0.00 \\
(0.001)\end{array}$ & $\begin{array}{c}0.02 \\
(0.015)\end{array}$ \\
\hline $\begin{array}{l}\text { Economic orthodoxy } \\
\text { (lagged once) }\end{array}$ & & $\begin{array}{c}0.02^{*} \\
(0.009)\end{array}$ & \\
\hline Central bank & & & -0.22 \\
\hline Independence & & & $(2.067)$ \\
\hline $\begin{array}{l}\text { Economic orthodoxy } \\
\text { (party manifesto) }\end{array}$ & & & $\begin{array}{c}-0.25^{*} \\
(0.147)\end{array}$ \\
\hline (1960s reference) & $(0.818)$ & & $(0.747)$ \\
\hline 1980s dummy & 0.56 & $-0.11^{* *}$ & $4.82^{* * *}$ \\
\hline (1960s reference) & $(0.932)$ & $(0.046)$ & $(1.362)$ \\
\hline 1990s dummy & -1.04 & $-0.13^{* *}$ & 0.38 \\
\hline (1960s reference) & $(0.710)$ & $(0.055)$ & $(1.087)$ \\
\hline 2000s dummy & $-2.26^{* * *}$ & -0.06 & -0.32 \\
\hline (1960s reference) & $(0.690)$ & $(0.077)$ & $(1.019)$ \\
\hline Constant & $\begin{array}{c}-0.14 \\
(1.204)\end{array}$ & $\begin{array}{c}-0.38 \\
(0.251)\end{array}$ & $\begin{array}{l}8.29 * * * \\
(1.902)\end{array}$ \\
\hline Observations & 94 & 78 & 94 \\
\hline R-squared & 0.21 & 0.73 & \\
\hline Number of countries & 21 & 21 & 21 \\
\hline Country fixed effects & Yes & Yes & No \\
\hline Time effects & Yes & Yes & Yes \\
\hline R-squared within model & 0.21 & 0.73 & 0.78 \\
\hline R-squared overall model & 0.04 & 0.29 & 0.61 \\
\hline R-squared between model & 0.00 & 0.07 & 0.32 \\
\hline
\end{tabular}




\section{Recent LEQS papers}

Monastiriotis, Vassilis \& Tunali, Cigdem “The Sustainability of External Imbalances in the European Periphery" Paper No. 106, March 2016

Louri, Helen \& Migiakis, Petros M. “Bank Lending Margins in the Euro Area: The Effects of Financial Fragmentation and ECB Policies" Paper No. 105, February 2016

Bartlett, Will \& Prica, Ivana. "Interdependence between Core and Peripheries of the European Economy: Secular Stagnation and Growth in the Western Balkans “ Paper No. 104, February 2016

Bojar, Abel. "The Electoral Advantage of the Left in Times of Fiscal Adjustment" Paper No. 103, January 2016

Westlake, Martin. "Chronicle of an Election Foretold: The Longer-Term Trends leading to the 'Spitzenkandidaten' procedure and the Election of Jean-Claude Juncker as European Commission President" Paper No. 102, January 2016

Farina, Francesco \& Tamborini, Roberto. “Europe's Great Divide. A geo-economic-political map" Paper No. 101, December 2015

De Santis, Roberta \& Lasinio, Cecilia Jona. “Environmental Policies, Innovation and Productivity in the EU" Paper No. 100, November 2015

Durazzi, Niccolo. "Inclusive unions in a dualised labour market? The challenge of organising labour market policy and social protection for labour market outsiders" Paper No. 99, October 2015

Costa Font, Joan \& Cowell, Frank. “European Identity and Redistributive Preferences" Paper No. 98, September 2015

Ascani, Andrea, Crescenzi, Riccardo \& Iammarino, Simona. "Economic Institutions and the Location Strategies of European Multinationals in their Geographical Neighbourhood" Paper No. 97, August 2015

Borrell-Porta, Mireia. "Do family values shape the pace of return to work after childbirth?" Paper No. 96, July 2015

Costa Font, Joan \& Kossarova, Lucia. “Anthropometric Dividends of Czechoslovakia's Break Up” Paper No. 95, June 2015

Wratil, Christopher.."Democratic Responsiveness in the European Union: the Case of the Council" Paper No. 94, June 2015

Crescenzi, Riccardo, Pietrobelli, Carlo \& Rabellotti, Roberta. "Location Strategies of Multinationals from Emerging Countries in the EU Regions" Paper No. 93, May 2015

Burger, Anna S. "Extreme working hours in Western Europe and North America: A new aspect of polarization" Paper No. 92, May 2015

Bojar, Abel." Biting the Hand that Feeds: Reconsidering Partisanship in an Age of Permanent Austerity" Paper No. 91, April 2015

Cesaroni , Tatiana \& De Santis, Roberta. "Current account "Core-periphery dualism" in the EMU" Paper No. 90, March 2015 


\section{LEQS}

European Institute London School of Economics Houghton Street WC2A 2AE London Email: euroinst.LEQS@lse.ac.uk

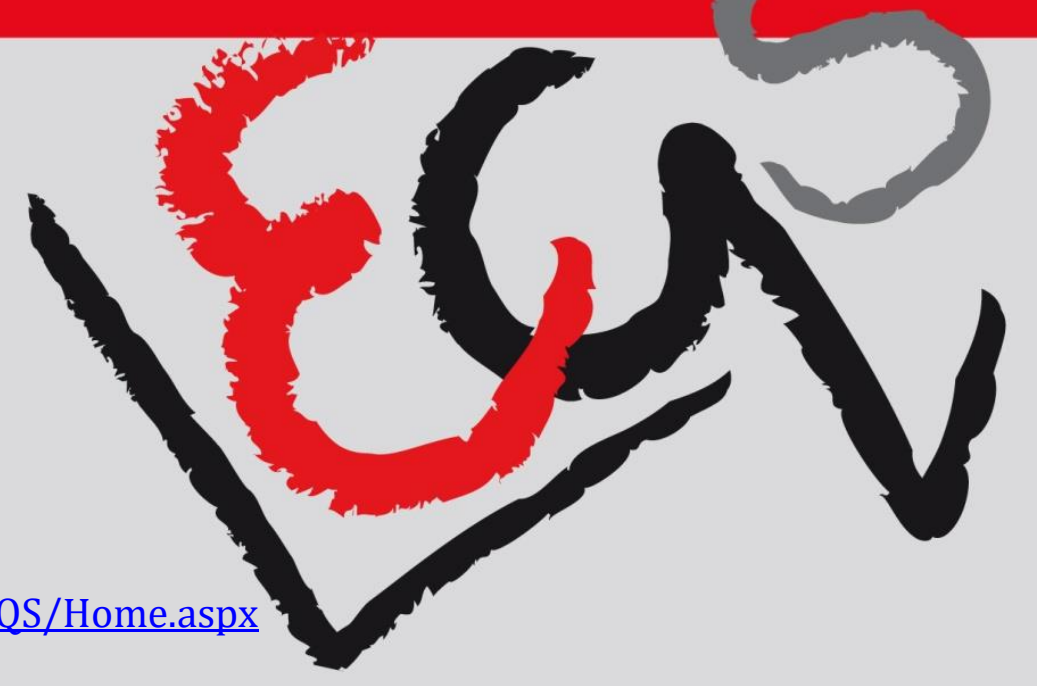

